\title{
Predicting targets of compounds against neurological diseases using cheminformatic methodology
}

Katarina Nikolic ${ }^{1}$, Lazaros Mavridis ${ }^{2}$, Oscar M. Bautista-Aguilera ${ }^{3}$, José Marco-

Contelles $^{3}$, Holger Stark ${ }^{4}$, Maria do Carmo Carreiras ${ }^{5}$, Ilaria Rossi ${ }^{6}$, Paola Massarelli ${ }^{6}$,

Danica Agbaba ${ }^{1}$, Rona R. Ramsay ${ }^{2}$, and John B. O. Mitchell ${ }^{2}$

${ }^{1}$ Institute of Pharmaceutical Chemistry, Faculty of Pharmacy, University of Belgrade, Vojvode Stepe 450, 11000 Belgrade, Serbia

${ }^{2}$ Biomedical Sciences Research Complex and EaStCHEM School of Chemistry, University of St Andrews, St Andrews, Scotland, KY16 9ST, UK

${ }^{3}$ Laboratorio de Química Médica, Instituto de Química Orgánica General, Consejo

Superior de Investigaciones Científicas, C/Juan de la Cierva 3, 28006 Madrid, Spain

${ }^{4}$ Heinrich Heine University, Institute of Pharmaceutical and Medicinal Chemistry, Universitaetsstr. 1, 40225 Duesseldorf, Germany

5 iMed.UL - Research Institute for Medicines and Pharmaceutical Sciences, Faculty of Pharmacy, University of Lisbon, Avda. Prof. Gama Pinto, 1649-003 Lisbon, Portugal

${ }^{6}$ Dipartimento di Scienze Mediche, Chirurgiche e Neuroscienze, University of Siena, Strada delle Scotte 6, 53100 SIENA, Italy.

\section{*Corresponding Author:}

Katarina Nikolic PhD Pharm, Department of Pharmaceutical Chemistry Faculty of Pharmacy, University of Belgrade

Vojvode Stepe 450

11000 Belgrade, Serbia

e-mail: knikolic@ pharmacy.bg.ac.rs

tel. +381-63-84-30-677, +381-11-3951-259

fax. $+381-11-397-43-49$ 
Keywords: multi-targeted ligands; circular fingerprints; off-target study; ChE; MAO; histamine $\mathrm{H} 3$ receptor; HMT

\section{Abbreviations}

AD: Alzheimer's disease

AChE: acetylcholinesterase

BuChE: butyrylcholinesterase

CFP: Circular Fingerprint

3D-QSAR - 3D-quantitive structure-activity relationship

EDTA: ethylenediaminetetraacetic acid

FP: false positive

GSK-3: glycogen synthase kinase 3

HMT: histamine N-methyltransferase

$\mathrm{H}_{3} \mathrm{R}$ : histamine $\mathrm{H}_{3}$-receptor

5-HT $1 \mathrm{a}:$ 5-hydroxytryptamine-1a (serotonin)

5-HT $2 \mathrm{a}$ : 5-hydroxytryptamine-2a (serotonin)

5-HT $2 \mathrm{c}$ 5-hydroxytryptamine-2c (serotonin)

MAO-A: monoamine oxidase A

MAO-B: monoamine oxidase B

MCC: Matthews Correlation Coefficient

MTDL: multi-target-directed ligand

NMDA receptors: N-methyl-D-aspartate receptor

nAChRs: nicotinic acetylcholine receptors 
8-OH-DPAT: ( \pm )-8-Hydroxy-2-dipropylaminotetralin

PDE-4: phosphodiesterase 4

PD: Parkinson's disease

RMSEE: Root Main Square Error of Estimation

RMSEP: Root Main Square Error of Prediction

SERT: serotonin transporter

TP: true positive

Tris: tris(hydroxymethyl)aminomethane

WADA: World Anti-Doping Agency

\begin{abstract}
Recently developed multi-targeted ligands are novel drug candidates able to interact with monoamine oxidase (MAO) A and B; acetylcholinesterase (AChE) and butyrylcholinesterase (BuChE); or with histamine $\mathrm{N}$-methyltransferase (HMT) and histamine $\mathrm{H}_{3}$-receptor $\left(\mathrm{H}_{3} \mathrm{R}\right)$. These proteins are drug targets in the treatment of depression, Alzheimer's disease, obsessive disorders, and Parkinson's disease.

A probabilistic method, the Parzen-Rosenblatt Window approach, was used to build a "predictor" model using data collected from the ChEMBL database. The model can be used to predict both the primary pharmaceutical target and off-targets of a compound based on its structure. Molecular structures were represented based on the circular fingerprint methodology. The same approach was used to build a "predictor" model from the DrugBank dataset to determine the main pharmacological groups of the compound. The study of off-target interactions is now recognised as crucial to the understanding of both drug action and toxicology. Primary pharmaceutical targets and off-targets for the novel multi-target ligands were examined by use of the developed cheminformatic method.
\end{abstract}


Several multi-target ligands were selected for further study, as compounds with possible additional beneficial pharmacological activities. The cheminformatic targets identifications were in agreement with four 3D-QSAR $\left(\mathrm{H}_{3} \mathrm{R} / \mathrm{D}_{1} \mathrm{R} / \mathrm{D}_{2} \mathrm{R} / 5-\mathrm{HT}_{2 \mathrm{a}} \mathrm{R}\right)$ models and by in vitro assays for serotonin $5-\mathrm{HT}_{1 \mathrm{a}}$ and $5-\mathrm{HT}_{2 \mathrm{a}}$ receptor binding of the most promising ligand (71/MBA-VEG8).

\section{Introduction}

The diverse cerebral mechanisms implicated in neurodegenerative disorders [1] and neurological diseases [2-6] and the heterogeneous but overlapping nature of phenotypes indicated that multitarget strategies may be appropriate for the improved treatment of complex brain diseases. It is now accepted that drug action can involve plural targets and that polypharmacology - interacting with multiple targets to address disease in more subtle and effective ways - will be a key pharmacological concept in future.

MTDL approach [7-9] has been applied for development of CNS drugs with improved efficacy compared to their precursors, such as dopamine $\mathrm{D}_{2} / \mathrm{D}_{3} / 5-\mathrm{HT}_{2 \mathrm{~A}}$ antagonism plus 5-HT $1 \mathrm{~A}$ partial agonism or dual PDE-4/ GSK-3 inhibitors for therapy of schizophrenia [10-12], monoamine reuptake inhibition plus 5- $\mathrm{HT}_{2 \mathrm{C}}$ antagonist properties for tricyclic antidepressants [13-15], multi-target AChE/BuChE/MAO-A/MAO-B inhibitors for therapy of neurodegenerative Alzheimer's (AD) and Parkinson's diseases (PD) [7, 16, 17], and range of CNS drug candidates with additional activity on various targets [18-20]. The potential clinical advantages of novel classes of multi-target agents are efficacy and speed of action, improved tolerance, and therapeutic range [8, 9, 13]. Therefore, development of multi-targeted compounds, with selective ranges of cross-reactivity, as novel drug candidates against neurological diseases was one of the main aims of our recent studies [21-35].

Understanding how the neurotransmitter systems interact is also important in optimizing therapeutic strategies. Pharmacological intervention on one will often influence another, such as the well-established serotonin-dopamine interaction $[36,37]$ or the dopamine- 
glutamate interaction $[38,39]$. This is a second reason to design compounds with specific, known cross-reactivity. An example of a drug with activity on different neurotransmitter systems is the cognitive enhancer, memantine, that binds as an uncompetitive antagonist at glutamatergic NMDA receptors [40] inhibiting the influx of $\mathrm{Ca}^{2+}$ ions that would result in neuronal excitotoxicity. Memantine also acts as a noncompetitive antagonist at the $5-\mathrm{HT}_{3}$ receptor and binds to dopamine $\mathrm{D}_{2}$ receptors and nAChRs [41].

Many compounds already in databases have been investigated for multiple targets as part of drug-discovery programs. Mining this information can provide experimental information useful for building pharmacophores. Data for three groups of new dual or multi-target compounds were also used in this process and to develop 3D-QSAR models for activity evaluation at the selected targets. The first group contains novel carbonitrileaminoheterocyclic inhibitors of both MAO A and B enzymes [21]. More selective MAO A inhibition was observed for dicarbonitrile aminofuran derivatives of the dataset [21].

The second group includes acetylene/indol/piperidines [22-25] and pyridine derivatives $[26,27]$, as compounds with appreciable inhibitory profile for MAO, AChE, and BuChE. These agents are potentially effective multi-targeted ligands in therapy for Alzheimer's disease $[42,43]$.

The third group contains the recently synthesised multipotent histamine $\mathrm{H}_{3} \mathrm{R}$ antagonists that simultaneously possess strong inhibitory potency on catabolic HMT enzyme [28, 29]. These compounds are dual acting procognitive agents with possible beneficial effects in many psychiatric and neurodegenerative diseases [34, 35].

We have previously demonstrated that prohibited substances can be classified into athletic performance-enhancing classes using MACCS, CDK, and UFS-MACCS hybrid cheminformatics descriptors and machine learning methods including Random Forest, kNearest Neighbours and Naive Bayes [44-46]. In silico prediction of protein targets is a new research area useful for understanding molecular bioactivities, performanceenhancing effects of molecules, target predictions in early drug development and toxicology [47-54], allowing the determination of both the primary pharmaceutical target and the off-targets from the structure of a compound. In silico ligand-target prediction helps us both to infer and to understand molecular bioactivities of test compounds. As 
well as being valuable for understanding the primary pharmaceutical roles of molecules, prediction of ligand-target associations facilitates both in silico polypharmacology and toxicology. Our interest is in predicting ligand-target associations that will allow us to define binding profile of ligand and in suggesting theoretical and experimental approaches directed towards gaining a deeper understanding of possible pharmacological effects. Our novel methodology, based on Circular Fingerprint (CFP) descriptors of compounds [55] and information data mined in the ChEMBL database, was very successfully applied in prediction of unexplored compound-to-target associations using a set of the WADA prohibited compounds [56]. A similar approach [56] was now applied to determine primary pharmaceutical targets and off-targets for our novel multi-target ligands (1-134) [21-29] as a crucial step in understanding the pharmacological and toxicological profiles of these novel compounds. Incorporation of target predictions into our drug design workflow represents one of the main advances of this study.

The publicly available ChEMBL database [57] contains bioactivity data for hundreds of thousands of different molecules on thousands of protein targets. When this information is combined with data from sources such as DrugBank [58], results can also be associated with specific biological and pharmacological activities. One of the first steps of our methodology is to apply a clustering algorithm capable of identifying structurally different groups of ligands and finding the optimum number of clusters for a given database. Those molecules, which have been examined in different assays, may have activities for more then one target. The target prediction methods presented here can predict unexplored compound-to-target associations and patterns of activity against the whole set of targets to be assessed. Our approach allows identification of novel compounds associated with a given pharmacological function.

These predictions can help to early identify any potential beneficial pharmacological effects, or unwanted side effects, of the novel multi-target agents [21-29] examined in this study. The compounds with better pharmacological activity profiles can be further examined by 3D-QSAR for their interaction with the targets, and then selected for experimental testing. Application of these cheminformatic and 3D-QSAR methods in early stage of drug discovery could significantly reduce the need for animal or human experiments. Our results can be interpreted as a quantitative assessment of protein-target 
interactions that will prevent unpromising novel compounds being examined in vitro and in vivo.

\section{Methods}

\section{Filtered and Refined families of the ChEMBL Dataset}

The ChEMBL database presently has 8,845 targets and 1,059,559 unique compounds, which are connected with the targets, based on experimental activity data derived from 44,682 publications. Each of the targets has compounds associated with it. Each such association comes from the experimental data indicating activity of the molecule against the target. However, some molecules are found to be inactive. A compound in ChEMBL database can be associated with more then one target family. In order to predict whether a given molecule will be active against a particular target, we first applied a number of rules on the ChEMBL dataset in order to generate sets of molecules that are experimentally determined to be bioactive $\left(\mathrm{IC}_{50}(\leq 50 \mu \mathrm{M}), \mathrm{K}_{\mathrm{i}}(<20 \mu \mathrm{M}), \mathrm{K}_{\mathrm{d}}(\leq 10 \mu \mathrm{M})\right.$, $\mathrm{EC}_{50}(\leq 40 \mu \mathrm{M}), \mathrm{ED}_{50}(\leq 40 \mu \mathrm{M})$, potency $(\leq 10 \mu \mathrm{M})$, activity $(\geq 40 \%)$, inhibition $\left.(\geq 45 \%)\right)$. These rules depend on the ranges of values against that target and the distribution of values of the relevant quantity within ChEMBL [54, 56]. This process generates bioactivity based filtered families. Our recently developed PFClust clustering [59] was

applied to all the filtered ChEMBL families, which subdivided each family into smaller groups based both on ligand structure and their proven activity on a given protein target $[54,56]$. The compounds were clustered on the basis of their chemical structures, described by Circular Fingerprints (CFP) [55]. This leads to a set of refined families, each consisting of a group of molecules, which share similar chemical structure and bioactivity. The refined families of the ChEMBL dataset will allow us to identify the different sets of ligands [54, 56, 59].

\section{Molecular fingerprints and similarities}

The studied molecules are represented as CFP vectors [55]. Pairwise similarity between two molecules is calculated by Tanimoto similarity scores [60]. The obtained Tanimoto similarity scores are then transformed into probabilities (pairwise p-values) using an 
appropriate kernel function. The Gaussian distribution was proven to be the best suited kernel function for the refined ChEMBL dataset [56]. In order to predict molecule-target pairs, we had to calculate how similar a given molecule $x_{i}$ is to the members of family $\omega$ $=\left\{x_{1}, x_{2}, \ldots, x_{n}\right\}$ using the refined ChEMBL dataset. We first calculated the distribution of $p\left(t\left[x_{i}, \omega\right]\right)$ between molecule $x_{i}$ and the known members of $\omega$. The probability density function of $p\left(t\left[x_{i}, \omega\right]\right)$ is then estimated by use of the Parzen-Rosenblatt (PR) [61, 62] kernel density estimation method.

\section{Methodology validation}

Our methodology is further validated by use of a fivefold Monte Carlo cross-validation for: the original ChEMBL dataset with all the compounds assigned to their label based ChEMBL families; the bioactivity-based filtered ChEMBL families; and finally the refined ChEMBL families obtained by PFClust clustering of the filtered dataset. In each cross-validation, we remove $10 \%$ of the members of each family, which are then used as a test set of queries. To investigate the relative performances using the three different definitions of families, we calculated two validation metrics. To investigate the relative performance of each methodology, we classified as a true positive (TP) a hit to the parent family from which the query compound was taken, and as false positives (FP) hits to all other families. The TPs and FPs obtained in the first four top hits for each query in all the cross-validation runs for each of the three definitions of families were used to calculate the Matthews Correlation Coefficient (MCC) [63], as a measure of prediction success. The results of the fivefold Monte Carlo cross-validation proved that the best performing model was the one based on the refined families [56].

\section{Identifying the off-targets of the novel multipotent compounds}

We used 134 novel drug candidates (1-134) (Figure 1) able to interact with MAO A and $\mathrm{B}$; $\mathrm{AChE}$ and BuChE; or with $\mathrm{HMT}$ and histamine $\mathrm{H}_{3}$-receptor (Table 1), as queries against the refined ChEMBL dataset [56].

Figure 1. General structural formulas of the examined compounds 1-134 [21-29]. Stereocenters are indicated with a star $(*)$. 
Table 1. Compounds examined in this study [21-29].

Figure 2. Target prediction methodology applied for a query compound (1-134) using the refined ChEMBL dataset.

For the three classes of compounds (Figure 1: 1-134) we used our cheminformatic workflow (Figure 2) to retrieve from the refined ChEMBL dataset the most significant families having $\mathrm{p}$-values less then 0.10 (PR-score $\leq 0.10$ ). This allows us to identify relevant biological targets for each group of studied compounds. To validate the methodology, we first checked whether these molecules have experimentally determined activities against these targets in ChEMBL. We created a matrix in which the rows were the examined compounds, the columns were the relevant families retrieved from ChEMBL, and the values were the relevant values of the Parzen-Rosenblatt function $\mathrm{f}\left(\mathrm{x}_{\mathrm{i}}, \omega\right)$. Each row of this matrix was considered as a vector and we calculated the pairwise Euclidean distances between the points. The calculated distances were further used to

allow PFClust to cluster the examined compounds. For each class of ligands, we performed a ChEMBL database search and a vector of PR-scores against the refined families was retrieved. Using these position vectors for each compound, we calculated the Euclidean distances between the resulting points and a similarity matrix was created. Finally, we clustered the vectors using PFClust [59].

\section{D-QSAR modeling}

Based on the ranges and distribution of obtained PR-scores for the MAO/ChE inhibitors against the refined ChEMBL dataset was decided to examine by 3D-QSAR studies all compounds with target's PR-score $\leq 0.17$, in order to allow for cases missed from 2D structural fingerprints. The group of compounds with the top predictions of the $\mathrm{H}_{3} \mathrm{R} /$ dopamine- $\mathrm{D}_{1} \mathrm{R} /$ dopamine- $\mathrm{D}_{2} \mathrm{R} /$ serotonine-5- $\mathrm{HT}_{2 \mathrm{a}}$ targets (PR-score $\leq 0.17$ ) was further evaluated by the corresponding 3D-QSAR $\left(\mathrm{H}_{3} \mathrm{R} / \mathrm{D}_{1} \mathrm{R} / \mathrm{D}_{2} \mathrm{R} / 5-\mathrm{HT}_{2 \mathrm{a}}\right)$ models. The $\mathrm{H}_{3} \mathrm{R}$ (pKi: 5.9-10.1) activities of 35 quinoline/piperidine derivatives (Figure 1: 101-134) $[28,29]$, were used for the 3D-QSAR $\left(\mathrm{H}_{3} \mathrm{R}\right)$ model building. 
Also, dopamine $\mathrm{D}_{1} \mathrm{R}$ (pKi: 4.8-8.5), dopamine $\mathrm{D}_{2} \mathrm{R}$ (pKi: 5.1-8.6), and serotonin 5- $\mathrm{HT}_{2 \mathrm{a}}$ (pKi: 4.0-9.7) antagonistic activities of haloperidol, clozapine, and 11 novel indol derivatives (Figure 3) [64], were used for 3D-QSAR $\left(D_{1} R\right)$, 3D-QSAR $\left(D_{2} R\right)$, and 3DQSAR(5-HT $2 \mathrm{a})$ modeling.

Figure 3. General structural formula of the indol derivatives used for 3D-QSAR $\left(D_{1} R\right)$, 3D-QSAR $\left(\mathrm{D}_{2} \mathrm{R}\right)$, and 3D-QSAR(5-HT $\left.2 \mathrm{a}\right)$ modeling.

Dominant forms of all the compounds at physiological $\mathrm{pH}$ [65] were further used for geometry optimisation by the Hartree-Fock/3-21G method [66, 67]. The 3D-QSAR studies of the optimised molecular models were performed by use of the Pentacle 1.0.6 program [68]. The quality of the obtained 3D-QSAR $\left(\mathrm{H}_{3} \mathrm{R} / \mathrm{D}_{1} \mathrm{R} / \mathrm{D}_{2} \mathrm{R} / 5-\mathrm{HT}_{2 \mathrm{a}}\right)$ models was examined by use of: leave-one-out cross-validation $\left(\mathrm{Q}^{2}\right)$, correlation coefficient $\left(\mathrm{R}^{2}\right.$ Observed vs. Predicted), RMSEE of training set, and external validation - RMSEP of test set $[69,70]$.

\section{In Vitro Receptor Binding}

\section{General procedures}

The compound 71/MBA-VEG8 was tested for in vitro affinity for serotonin 5-HT 1 A, 5$\mathrm{HT}_{2 \mathrm{~A}}$ and 5- $\mathrm{HT}_{2 \mathrm{C}}$ receptors by radioligand binding assays. The compound was dissolved in 5\% DMSO. The following receptors, their tissue sources, and specific radioligands were used: (a) rat brain cortex serotonin $5-\mathrm{HT}_{1 \mathrm{~A}}$ receptor, $\left[{ }^{3} \mathrm{H}\right]-8-\mathrm{OH}-\mathrm{DPAT}$; (b) rat brain cortex serotonin $5-\mathrm{HT}_{2 \mathrm{~A}}$ receptor, $\left[{ }^{3} \mathrm{H}\right]$ ketanserin; (c) rat brain cortex serotonin $5-\mathrm{HT}_{2 \mathrm{C}}$ receptor, $\left[{ }^{3} \mathrm{H}\right]$ mesulergine. Total and non-specific binding were determined and specific binding calculated as the difference between total and non-specific binding. Blank experiments were carried out to determine the effect of 5\% DMSO on the binding and no effects were observed. Competition experiments were analyzed by PRISM 5 (GraphPadPrism ${ }^{\circledR}$, 1992-2007, GraphPad Software, Inc., La Jolla, CA, USA) to obtain the concentration of unlabeled drug that caused $50 \%$ inhibition of ligand binding $\left(\mathrm{IC}_{50}\right)$, with six concentrations of test compound, each performed in triplicate. The $\mathrm{IC}_{50}$ values obtained were used to calculate apparent inhibition constants $\left(K_{\mathrm{i}}\right)$ by the method of Cheng and Prussoff [71], from the following equation: $K_{\mathrm{i}}=\mathrm{IC}_{50} /\left(1+\mathrm{S} / \mathrm{K}_{\mathrm{D}}\right)$ where $\mathrm{S}$ 
represents the concentration of the hot ligand used and $K_{\mathrm{D}}$ its receptor dissociation constant $\left(K_{D}\right.$ values, obtained by Scatchard analysis [72], were calculated for each labeled ligand).

\section{5-HT $T_{1 A}$ binding assay}

Radioligand binding assays were performed following a published procedure [73]. Cerebral cortex from male Sprague-Dawley rats (180-220 g) was homogenized in 20 volumes of ice-cold Tris- $\mathrm{HCl}$ buffer $(50 \mathrm{mM}, \mathrm{pH}$ 7.7) with a Polytron PT10, Brinkmann Instruments (setting 5 for $15 \mathrm{sec}$ ), and the homogenate was centrifuged at $50000 \mathrm{~g}$ for $10 \mathrm{~min}$. The resulting pellet was then resuspended in the same buffer, incubated for $10 \mathrm{~min}$ at $37^{\circ} \mathrm{C}$, and centrifuged at $50000 \mathrm{~g}$ for $10 \mathrm{~min}$. The final pellet was resuspended in 80 volumes of the Tris- $\mathrm{HCl}$ buffer containing $10 \mu \mathrm{M}$ pargyline, $4 \mathrm{mM} \mathrm{CaCl}_{2}$, and $0.1 \%$ ascorbate. To each assay tube was added the following: $0.1 \mathrm{~mL}$ of the drug dilution ( $0.1 \mathrm{~mL}$ of distilled water if no competing drug was added), $0.1 \mathrm{~mL}$ of $\left[{ }^{3} \mathrm{H}\right]-8$-hydroxy-2(di-n-propylamino)tetralin $\left(\left[{ }^{3} \mathrm{H}\right]-8-\mathrm{OH}-\mathrm{DPAT}\right)$ (170.0 Ci/mmol, Perkin Elmer Life Sciences, Boston, MA, USA) in the same buffer as above to achieve a final assay concentration of $0.1 \mathrm{nM}$, and $0.8 \mathrm{~mL}$ of resuspended membranes. The tubes were incubated for $30 \mathrm{~min}$ at $37^{\circ} \mathrm{C}$, and the incubations were terminated by vacuum filtration through Whatman GF/B filters (Brandel Biomedical Research and Laboratories Inc., Gaithersburg, MD, USA). The filters were washed twice with $5 \mathrm{~mL}$ of ice-cold Tris- $\mathrm{HCl}$ buffer, and the radioactivity bound to the filters was measured by liquid scintillation spectrometer (Packard TRI-CARB ${ }^{\circledR}$ 2000CA - Packard BioScience s.r.l., Pero, Milan, Italy). Specific $\left[{ }^{3} \mathrm{H}\right]-8-\mathrm{OH}-\mathrm{DPAT}$ binding was defined as the difference between binding in the absence and presence of 5-HT $(10 \mu \mathrm{M})$.

\section{5-HT $T_{2 A}$ and 5-HT $2 \mathrm{C}$ binding assays}

Radioligand binding assays were performed as previously reported by Herndon et al [74]. Briefly, frontal cortical regions of male Sprague-Dawley rats (180-220 g) were dissected on ice and homogenized (1:10 w/v) in ice-cold buffer solution (50 mM Tris $\mathrm{HCl}, 0.5 \mathrm{mM}$ EDTA, and $10 \mathrm{mM} \mathrm{MgCl}_{2}$ at $\mathrm{pH}$ 7.4) with a Polytron PT10 (setting 5 for $15 \mathrm{sec}$ ) and centrifuged at $3000 \mathrm{~g}$ for $15 \mathrm{~min}$. The pellet was resuspended in buffer $(1: 30 \mathrm{w} / \mathrm{v})$, 
incubated at $37{ }^{\circ} \mathrm{C}$ for $15 \mathrm{~min}$ and then centrifuged twice more at $3000 \mathrm{~g}$ for $10 \mathrm{~min}$ (with resuspension between centrifugations). The final pellet was resuspended in buffer that also contained $0.1 \%$ ascorbate and $10^{-5} \mathrm{M}$ pargyline.

Assays were performed in triplicate in a $2.0 \mathrm{~mL}$ volume containing $5 \mathrm{mg}$ wet weight of tissue and $0.4 \mathrm{nM}\left[{ }^{3} \mathrm{H}\right]$ ketanserin hydrochloride $(88.0 \mathrm{Ci} / \mathrm{mmol}$; Perkin Elmer Life Sciences, Boston, MA, USA) for 5- $\mathrm{HT}_{2 \mathrm{~A}}$ receptor assays, and $10 \mathrm{mg}$ wet weight of tissue and $1 \mathrm{nM}\left[{ }^{3} \mathrm{H}\right]$ mesulergine (87.0 Ci/mmol; Amersham Biosciences Europe $\mathrm{GmbH}$ ) for 5$\mathrm{HT}_{2 \mathrm{C}}$ receptor assays. Cinanserin $(1.0 \mu \mathrm{M})$ was used to define nonspecific binding in the 5- $\mathrm{HT}_{2 \mathrm{~A}}$ assay. In the 5- $\mathrm{HT}_{2 \mathrm{C}}$ assays, mianserin $(1.0 \mu \mathrm{M})$ was used to define nonspecific binding, and $100 \mathrm{nM}$ spiperone was added to all tubes to block binding to 5-HT $\mathrm{HT}_{2 \mathrm{~A}}$ receptors. Tubes were incubated for $15 \mathrm{~min}$ at $37^{\circ} \mathrm{C}$, filtered on Schliecher and Schuell (Keene, NH, USA) glass fibre filters presoaked in polyethylene imine, and washed with $10 \mathrm{~mL}$ of ice-cold buffer. Filters were counted at an efficiency of $50 \%$.

\section{Results}

\section{Identifying the targets of the query molecules}

The TPs and FPs obtained in the first four top-ranked positions for each query compound in all the cross-validation runs for each of the three definitions of families confirmed previous observations that the refined families gave a significantly better predictivity (MCC: 0.66) [56]. Thus, for each of the four classes of compounds (Figure 1: 1-134), we examined the refined ChEMBL families using every such compound as a query. Relative performance of the cheminformatic methodology was further tested with true positives (TPs) and false positives (FPs) ligands, selected from the examined data set. Selective and potent ligands were used as TPs in the study: tacrine/donepezil (AChE/BuChE), FA73 (MAO-B), clorgiline (MAO-A), and 18-Hetero (HMT/ $\left.\mathrm{H}_{3}-\mathrm{R}\right)$. As FPs were used compounds with no activity on the specific target such as: clorgiline ( $\mathrm{AChE} / \mathrm{BuChE})$, tacrine/donepezil (MAO-B), tacrine/donepezil (MAO-A), and clorgiline (HMT/ $\left.\mathrm{H}_{3}-\mathrm{R}\right)$.

For all compounds, we calculated heat map with the top predictions (PR-score $\leq 0.10$ ) that summarizes the experimental validation for the most confident predictions (PR- 
scores $\leq 0.10$ ). The selected TPs and FPs confirmed very high predictive potential of the developed method. The top targets predictions for all examined compounds (Figure 1: 1134) by applying the cheminformatic methodology against the refined families ChEMBL are shown in Figure 4 and Supplementary Table 1. The same procedure is repeated for the queried compounds against DrugBank [58] dataset. The obtained results (Supplementary Figure 1) are then compared with ChEMBL results with the goal of associating specific biological/pharmacological activities with ligand-target interactions.

Figure 4. Ligand-target associations for all examined compounds (1-134), obtained by querying the 134 compounds against the refined ChEMBL dataset.

Supplementary Figure 1. Ligand-pharmacological group associations for all examined compounds (1-134), obtained by querying the 134 compounds against the refined DrugBank dataset.

\section{MAO-inhibitors}

For the first group of novel carbonitrile-aminoheterocyclic MAO inhibitors (Figure 1: 117) [21] were not predicted to interact with MAO within the top predictions (PR-score $\leq$ 0.10 ) by querying the 17 ligands against the refined ChEMBL families (Figure 4, Supplementary Table 1). Since the structures and activities of the novel class of MAO inhibitors (Figure 1: 1-17) [21] have just recently been published and still are not included in the ChEMBL dataset our cheminformatic method couldn't find significant similarity between the query compounds (Figure 1: 1-17) and the refined ChEMBL dataset.

For the carbonitrile-oxazole derivatives (Figure 1: 1/CN-D1a, 2/CN-D1b, 3/CN-D1c 4/CN-D1d, 5/CN-D1e, 6/CN-D1f, 7/CN-D2b) [21] affinity was predicted with a good PR-score (PR-score $\leq 0.10$ ) for caspase-1 and caspase-7 families. These MAO inhibitors were also classified as folic acid antagonists, antimetabolites-antineoplastics or protein kinase inhibitors by applying the cheminformatic methodology against the DrugBank 
dataset (Supplementary Figure 1, Supplementary Table 2). The targets retrieved from the ChEMBL data base (caspase families) were in accordance with the DrugBank results.

\section{MAO/ChE-inhibitors}

The MAO/ChE inhibitors are clustered by structure into three subgroups: acetylene/indol derivatives as potent inhibitors of MAO A and MAO B (Figure 1: 44-55) [25], the acetylene/indol/piperidines as MAO A, MAO B, AChE, and BuChE inhibitors (Figure 1: 18-43, 56-77, 79-85) [22-24], while the pyridine derivatives are AChE and BuChE inhibitors (Figure 1: 78, 86-100) [26, 27].

The top targets predictions for examined MAO/ChE inhibitors (Figure 1: 44-100) by applying the cheminformatic methodology against the refined ChEMBL dataset are shown in Figure 4 and Supplementary Table 1.

The compounds in the subgroup of acetylene/indol derivatives (Figure 1: 44-55) [25] are identified as MAO inhibitors; the acetylene/indol/piperidines (Figure 1: 18-43, 56-77, 7985) [22-24] are identified as MAO/ChE inhibitors; and the subgroup of pyridine derivatives (Figure 1: 78, 86-100) [26, 27] as ChE inhibitors within the top predictions $(\mathrm{PR}$-score $\leq$ 0.10) $($ Table 2). TP control were tacrine/donepezil (AChE/BuChE), FA-73 (MAO-B), and clorgiline (MAO-A), while clorgiline (AChE/BuChE), tacrine/donepezil (MAO-B), and tacrine/donepezil (MAO-A) were used as FPs. Good agreement obtained between the theoretical and the experimental results represents experimental confirmation of reliability and accuracy of the applied cheminformatic methodology.

Table 2. Experimental validation of the top ranked targets (PR-Scores $\leq 0.10)$ for the MAO/ChE inhibitors class (44-100). a) PR-Scores are derived by applying the cheminformatic methodology against the refined ChEMBL dataset.

Compounds 31/PF96-Donz-D8，33/PF96-Donz-D10，34/PF96-Donz-11，36/PF96Donz-D13, 60/Donz-D6, 62/Donz-D8, 63/Donz-D9, and 68/MBA-71, are identified as ligands for the histamine $\mathrm{H}_{3}$ receptor by applying the cheminformatic methodology against the refined ChEMBL dataset (Table 3). 
Compounds 62/Donz-D8, 63/Donz-D9, 67/MBA-50, 70/MBA-73, and 71/MBA-VEG8 are determined as ligands for dopamine $\mathrm{D}_{1}$ receptors by applying the cheminformatic methodology against the refined ChEMBL dataset (Figure 5, Table 3).

Compound 63/Donz-D9 is identified as a ligand for dopamine $\mathrm{D}_{2}$ receptors by applying the cheminformatic methodology against the refined ChEMBL dataset (Figure 5, Table $3)$.

Figure 5. Target prediction for 63/Donz-D9.

Compounds 57/Don-D3, 58/Don-D4, 59/Don-D5, 60/Don-D6, 69/MBA-72, 71/MBAVEG8，82/TC4-MBA-91，83/MBA-98F1，84/MBA-98F2, and 85/MBA-101 are identified as good ligands for serotonin 5- $\mathrm{HT}_{2 \mathrm{a}} \mathrm{R}$ receptors. Additionally, 71/MBA-VEG8 is determined as a very good ligand for $5-\mathrm{HT}_{1 \mathrm{a}} \mathrm{R}, 5-\mathrm{HT}_{2 \mathrm{c}} \mathrm{R}$, and $5-\mathrm{HT}_{5 \mathrm{a}} \mathrm{R}$ by applying the cheminformatic methodology against the refined ChEMBL dataset (Figure 6, Table 3).

Based on the ranges and distribution of PR-scores obtained for the MAO/ChE inhibitors against the refined ChEMBL dataset, was decided to increase the upper PR-score limit to 0.17 for further studies. A group of the selected compounds with the top predictions of the $\mathrm{H}_{3} \mathrm{R} / \mathrm{D}_{1} \mathrm{R} / \mathrm{D}_{2} \mathrm{R} / 5-\mathrm{HT}_{2 \mathrm{a}} \mathrm{R}$ targets (PR-score $\leq 0.17$ ) were further evaluated by $3 \mathrm{D}$ QSAR $\left(\mathrm{H}_{3} \mathrm{R}, \mathrm{D}_{1} \mathrm{R}, \mathrm{D}_{2} \mathrm{R}, 5-\mathrm{HT}_{2 \mathrm{a}} \mathrm{R}\right)$ studies and by in vitro $5-\mathrm{HT}_{1 \mathrm{a}} \mathrm{R}, 5-\mathrm{HT}_{2 \mathrm{c}} \mathrm{R}$, and 5$\mathrm{HT}_{2 \mathrm{a}} \mathrm{R}$ binding assays of the most promising ligand (71/MBA-VEG8) (Figure 5). The top ranked targets of the ligands obtained by the cheminformatic method were in good accordance with the corresponding activities of ligands predicted by the 3D-QSAR $\left(\mathrm{H}_{3} \mathrm{R} / \mathrm{D}_{1} \mathrm{R} / \mathrm{D}_{2} \mathrm{R} / 5-\mathrm{HT}_{2 \mathrm{a}} \mathrm{R}\right)$ models (Figure 6, Table 3$)$. These predictions are testable by future experiments.

Table 3. Experimental and 3D-QSAR validation of the top ranked targets for the $\mathrm{MAO} / \mathrm{ChE}$ inhibitors class (44-100). a) PR-Scores are derived by applying the cheminformatic methodology against the refined ChEMBL dataset. b) $p K i=\log (1 / \mathrm{Ki}), K i$ 
$[\mathrm{M}]$, c) $K i\left(5-\mathrm{HT}_{1 \mathrm{a}} \mathrm{R}\right)=1.08 \times 10^{-7} \pm 0,04 \mathrm{M}, \mathrm{IC}_{50}\left(5-\mathrm{HT}_{1 \mathrm{a}} \mathrm{R}\right)=2.40 \times 10^{-7} \pm 0,10 \mathrm{M}, \mathrm{Ki}(5-$

$\left.\mathrm{HT}_{2 \mathrm{a}} \mathrm{R}\right)=1.42 \times 10^{-8} \pm 0.57 \mathrm{M}, \mathrm{IC}_{50}\left(5-\mathrm{HT}_{2 \mathrm{a}} \mathrm{R}\right)=1.92 \times 10^{-8} \pm 0.77 \mathrm{M}$.

Figure 6. Target prediction for 71/MBA-VEG8.

The in vitro $5-\mathrm{HT}_{1 \mathrm{a}} \mathrm{R}$ and $5-\mathrm{HT}_{2 \mathrm{a}} \mathrm{R}$ binding assay for 71/MBA-VEG8 determined the $K i$ for $5-\mathrm{HT}_{1 \mathrm{a}} \mathrm{R}$ as $108 \mathrm{nM}$ and the $\mathrm{Ki}$ for $5-\mathrm{HT}_{2 \mathrm{a}} \mathrm{R}$ as $14.2 \mathrm{nM}$ (Figure 7).

Figure 7. Concentration-response curves of compound 71/MBA-VEG8 in in vitro assays for $5-\mathrm{HT}_{1 \mathrm{a}}\left(\mathrm{IC}_{50} 2.40 \times 10^{-7} \pm 0.10\right)(\mathbf{A})$ and for $5-\mathrm{HT}_{2 \mathrm{a}}\left(\mathrm{IC}_{50} 1.92 \times 10^{-8} \pm 0.77\right)(\mathbf{B})$

receptor binding. The curves were generated by non-linear regression to determine the $\mathrm{IC}_{50}$ values. Data points are the mean $\pm \mathrm{SD}$ of triplicate values as described in Methods.

These results experimentally confirmed high prediction capacity of the applied cheminformatic methodology. The in vitro binding assay of 71/MBA-VEG8 on 5-HT ${ }_{2 \mathrm{c}} \mathrm{R}$ determined no affinity. This result can be explained by the higher PR-score for 71/MBAVEG8 on 5-HT $2 \mathrm{c}$ R, then on $5-\mathrm{HT}_{1 \mathrm{a}} \mathrm{R}$ and $5-\mathrm{HT}_{2 \mathrm{a}} \mathrm{R}$.

The $\mathrm{MAO} / \mathrm{ChE}$ inhibitors were classified as serotonin antagonists and dopamine agonists by applying the cheminformatic methodology against DrugBank dataset (Supplementary Figure 1, Supplementary Table 2). The main targets retrieved from the ChEMBL data base (5- $\mathrm{HT}_{1}, 5-\mathrm{HT}_{2}, \mathrm{D}_{1}, \mathrm{D}_{2}$ receptors) were in agreement with the DrugBank results for the $\mathrm{MAO} / \mathrm{ChE}$ inhibitors.

\section{$\mathrm{H}_{3} \mathrm{R} / \mathrm{HMT} / \mathrm{ChE}$ ligands}

The third group (101/1-Hetero-134/34-Hetero) contains multipotent histamine $\mathrm{H}_{3}$ receptor $\left(\mathrm{H}_{3} \mathrm{R}\right)$ antagonists with inhibiting activity on HMT enzyme [28, 29]. For several ligands of the third group, 109/9-Hetero, 128/28-Hetero, 131/31-Hetero, 133/33- 
Hetero, 134/34-Hetero, is experimentally determined inhibiting activity on $\mathrm{AChE} / \mathrm{BuChE}$ enzymes too [29].

The top targets predictions for examined $\mathrm{H}_{3} \mathrm{R} / \mathrm{HMT} / \mathrm{ChE}$ ligands (Figure 1: 101/1Hetero-134/34-Hetero) by applying the cheminformatic methodology against the refined ChEMBL dataset are shown in Figure 4 and Supplementary Table 1.

The piperidine/quinoline derivatives (Figure 1: 101/1-Hetero-134/34-Hetero) [28, 29] are defined as $\mathrm{H}_{3} \mathrm{R} / \mathrm{HMT}$ ligands within the top predictions (PR-score $\left.\leq 0.10\right)$ (Table 4). The 109/9-Hetero, 131/31-Hetero, and 133/33-Hetero compounds are also identified as $\mathrm{AChE} / \mathrm{BuChE}$ inhibitors by applying the cheminformatic methodology against the refined ChEMBL dataset (Table 4).

Table 4. Experimental validation of the top ranked targets (PR-Scores $\leq 0.10)$ for the $\mathrm{H}_{3} \mathrm{R} / \mathrm{HMT} / \mathrm{ChE}$ ligands (101/1-Hetero-134/34-Hetero). a) PR-Scores are derived by applying the cheminformatic methodology against the refined ChEMBL dataset.

For all top ranked targets (PR-Scores $\leq 0.10$ ) of the $\mathrm{H}_{3} \mathrm{R} / \mathrm{HMT} / \mathrm{ChE}$ ligands are experimentally confirmed strong ligand-target affinities (Table 4). The accordance between the predicted pharmacological targets and the in vitro activities of the $\mathrm{H}_{3} \mathrm{R} / \mathrm{HMT} / \mathrm{ChE}$ ligands (Table 4) has proved high accuracy and reliability of the applied cheminformatic methodology against the refined ChEMBL dataset.

Table 5. List of the top ranked targets predictions $(P R-S c o r e s \leq 0.10)$ for the $\mathrm{H}_{3} \mathrm{R} / \mathrm{HMT} / \mathrm{ChE}$ ligands (101/1-Hetero-134/34-Hetero). a) PR-Scores are derived by applying the cheminformatic methodology against the refined ChEMBL dataset.

Based on the identified off targets (Table 5) the compounds 102/2-Hetero, 131/31Hetero, 132/32-Hetero, and 133/33-Hetero are selected for further experimental study as promising novel agents with possible beneficial effects in treatment of depression, Alzheimer's disease, and obsessive disorders. 
Compounds 111/111-Hetero-124/124-Hetero are identified as potential antiproliferative compounds against colon adenocarcinoma cells, erythroleukemia cells, lymphoma cells, and lymphocytic leukemia cells.

The $\mathrm{H}_{3} \mathrm{R} / \mathrm{HMT} / \mathrm{ChE}$ ligands were classified as dopamine/histamine antagonists (antipsychotic agents), serotonin antagonists (antiemetic or antipsychotic agents) by applying the cheminformatic methodology against the DrugBank dataset (Supplementary Figure 1, Supplementary Table 2.). The targets retrieved from the ChEMBL data base $\left(\mathrm{H}_{1}, \mathrm{H}_{3}, \mathrm{NMDA}\right.$, and $\mathrm{D}_{2}$ receptors) accorded well with the DrugBank results.

\section{Discussion}

Our current methodology has confirmed to enhance the predictive power of the CFP representations, and that the filtering and refinement of ChEMBL families enriches our results. The refined ChEMBL dataset and our protein target prediction approach could serve as a baseline for further methodologies. The developed workflow represents a truly portable methodology that can easily be used in initial phase of drug design process.

Having thus fivefold cross-validated cheminformatic approach, we used it to identify the protein targets associated with the 134 multipotent compounds against neurological diseases able to interact with MAO A and B; AChE and BuChE; or with HMT and histamine $\mathrm{H}_{3}$-receptor. Across the three classes considered, we find a combination of expected and unexpected protein targets for the examined ligands. Good agreement between the predicted pharmacological targets and the experimental results for the $\mathrm{MAO} / \mathrm{ChE}$ and $\mathrm{H}_{3} \mathrm{R} / \mathrm{HMT} / \mathrm{ChE}$ ligands (Table 2 and 4) has proved high reliability and accuracy of the applied cheminformatic methodology.

For the MAO/ChE inhibitor, compound 71/MBA-VEG8, the cheminformatic method has determined serotonin $5-\mathrm{HT}_{1 \mathrm{a}} \mathrm{R}, 5-\mathrm{HT}_{2 \mathrm{a}} \mathrm{R}, 5-\mathrm{HT}_{2 \mathrm{c}} \mathrm{R}, 5-\mathrm{HT}_{5 \mathrm{a}} \mathrm{R}$, and $\mathrm{D}_{1} \mathrm{R}$ as possible offtargets. The compound 71/MBA-VEG8 with the top prediction of the 5- $\mathrm{HT}_{2 \mathrm{a}} \mathrm{R}$ and 5$\mathrm{HT}_{1 \mathrm{a}} \mathrm{R}$ targets was further examined by the in vitro $5-\mathrm{HT}_{2 \mathrm{a}} \mathrm{R}$ and $5-\mathrm{HT}_{1 \mathrm{a}} \mathrm{R}$ binding assay. 
The binding study has confirmed relatively strong affinity of the 71/MBA-VEG8: $K i$ (5$\left.\mathrm{HT}_{2 \mathrm{a}} \mathrm{R}\right)=14.2 \mathrm{nM}$ and $K i\left(5-\mathrm{HT}_{1 \mathrm{a}} \mathrm{R}\right)=108 \mathrm{nM}$ for the receptors.

Also, for set of compounds (ID: 31, 33, 34, 36, 57-60, 62, 63, 67-71, 82-85, 102) with the top prediction of $\mathrm{H}_{3} \mathrm{R} / \mathrm{D}_{1} \mathrm{R} / \mathrm{D}_{2} \mathrm{R} / 5-\mathrm{HT}_{2 \mathrm{a}} \mathrm{R}$ off-targets, we made 3D-QSAR bioactivity evaluation, obtaining a very good accordance between the cheminformatic and 3D-QSAR $\left(\mathrm{H}_{3} \mathrm{R} / \mathrm{D}_{1} \mathrm{R} / \mathrm{D}_{2} \mathrm{R} / 5-\mathrm{HT}_{2 \mathrm{a}} \mathrm{R}\right)$ results.

The observed or predicted affinities of 63/Donz-D9, 71/MBA-VEG8, 102/2-Hetero ligands for $5-\mathrm{HT}_{2 \mathrm{a}} \mathrm{R}, \mathrm{D}_{1} \mathrm{R}, \mathrm{D}_{2} \mathrm{R}$ could be explained with similarity between 63/Donz-D9 and clozapine chemical scaffolds, as well as between 71/MBA-VEG8, 102/2-Hetero and haloperidol chemical scaffolds (Figure 8).

Figure 8. Chemical scaffolds of 63/Donz-D9, 71/MBA-VEG8, 102/2-Hetero, haloperidol, and clozapine.

Serotonin (5-HT) plays a major role in the pathophysiology and treatment of depression, anxiety, schizophrenia, and various forms of dementia including Alzheimer's disease [75]. Therefore, serotonin 5- $\mathrm{HT}_{1 \mathrm{a}}$ partial agonists/antagonists and 5- $\mathrm{HT}_{2 \mathrm{a}}$ antagonists have shown effectiveness in improving cognition in depression [8, 13, 15, 75], schizophrenia [14, 76-78], Alzheimer's and Parkinson's diseases [79-82].

Based on results of previous studies [76, 83] it was proposed that drugs with potent serotonin $5-\mathrm{HT}_{1 \mathrm{a}}$ or $5-\mathrm{HT}_{2 \mathrm{a}}$ antagonistic actions may improve cognition in various neurodegenerative disorders due to a association with NMDA receptors [84, 85].

Few recent studies of memantine, as a non-competitive antagonist of glutamatergic NMDA receptors [86, 87], demonstrated that this drug for treatment of AD also competitively inhibits both MAO-A and MAO-B in nanomolar range and inhibits the reuptakes of both DA and 5-HT. The mamantine induce 5- $\mathrm{HT}_{2 \mathrm{a}}$ receptor-mediated headtwitch response (HTR) and head-weaving side effects [88, 89]. These abnormal behaviours developed during mamantine therapy of $\mathrm{AD}$ were inhibited by coadministration of haloperidol $\left(\mathrm{D}_{1} / \mathrm{D}_{2} / 5-\mathrm{HT}_{2 \mathrm{a}}\right.$ antagonist $)$ or ketanserine $\left(5-\mathrm{HT}_{2 \mathrm{a}}\right.$ antagonist) [86]. 
Based on all these findings is assumed that multi-potent ligands targeting AChE/MAO$\mathrm{A} / \mathrm{MAO}-\mathrm{B}$ and also $\mathrm{D}_{1} / \mathrm{D}_{2} / 5-\mathrm{HT}_{2 \mathrm{a}} / \mathrm{H}_{3}$, such as 63/Donz-D9 and 71/MBA-VEG8, are promising novel drug candidates with improved efficacy and safety in treatment of Alzheimer's and related diseases.

Also, numerous pharmacological, preclinical and clinical studies proved that histamine $\mathrm{H}_{3} \mathrm{R}$ antagonists/inverse agonists facilitate the corticolimbic liberation of acetylcholine, noradrenaline, dopamine, glutamate, and serotonin $[2,3,5]$ and therefore demonstrate efficacy in diverse preclinical models of cognitive deficits [90].

Therefore, $\mathrm{H}_{3} / \mathrm{HMT}$ multi-target ligands with additional affinities for $\mathrm{D}_{2} / 5$ $\mathrm{HT}_{2 \mathrm{a}} / \mathrm{SERT} / \mathrm{NMDA}$, such as 102/2-Hetero, 131/31-Hetero, 132/32-Hetero, and 133/33Hetero, are promising novel procognitive agents with beneficial effects in treatment of various neurodegenerative diseases.

\section{Experimental}

The computations described in Methods were carried out on a custom-built computer using an Intel i3 processor @ 3.10Ghz with 4GB of RAM.

\section{Competing interests}

The authors (JBOM, LM) have received funding from WADA. Other then this sponsorship, the authors declare no conflict of interest.

\section{Acknowledgement}

This project has been carried out with the support of WADA. We also acknowledge financial support from the Scottish Universities Life Sciences Alliance (SULSA). OMBA and JMC thenk MINECO (Spain) for a fellowship, and support (SAF2012-33304), respectively. KN and DA acknowledge project supported by the Ministry of Education and Science of the Republic of Serbia, Contract \#172033. Further supports by Else Kröner-Fresenius-Stiftung, Translational Research Innovation - Pharma (TRIP), Fraunhofer-Projektgruppe für Translationale Medizin und Pharmakologie (TMP) (to HS) and the European COST Actions BM1007, CM1103 (including STSM 10295 to KN), and CM1207 are also gratefully acknowledged.

\section{References}


1. Goedert M, Spillantini MGA (2006) A century of Alzheimer's disease. Science 314: 777-781

2. Humbert-Claude M, Morisset S, Gbahou F, Arrang JM (2007) Histamine H3 and dopamine D2 receptor-mediated $[35 \mathrm{~S}] \mathrm{GTP} \gamma[\mathrm{S}]$ binding in rat striatum: Evidence for additive effects but lack of interactions. Biochem Pharmacol 73: 1172-1181

3. Garduno-Torres B, Trevino M, Gutierrez R, Arias-Montano JA (2007) Presynaptic histamine $\mathrm{H} 3$ receptors regulate glutamate, but not GABA release in rat thalamus. Neuropharmacology 52: 527-535

4. Dai H, Fu Q, Shen Y, Hu W, Zhang Z, Timmerman H, Leurs R, Chen Z (2007) The histamine $\mathrm{H} 3$ receptor antagonist clobenpropit enhances GABA release to protect against NMDA induced excitotoxicity through the $\mathrm{cAMP} /$ protein kinase A pathway in cultured cortical neurons. Eur J Pharmacol 563: 117-123

5. Threlfell S, Cragg SJ, Imre K, Turi GF, Coen CW, Greenfield SA (2004) HistamineH3 receptors inhibit serotonin release in substantia nigra pars reticulata. $\mathrm{J}$ Neurosci 24: 8704-8710

6. Gemkow MJ, Davenport AJ, Harich S, Ellenbroek BA, Cesura A, Hallett D (2009) The histamine $\mathrm{H} 3$ receptor as a therapeutic drug target for CNS disorders. Drug Discovery Today 14: 509-515

7. León R, Garcia AG, Marco-Contelles J (2013) Recent advances in the multitargetdirected ligands approach for the treatment of Alzheimer's disease. Med Res Rev 33: 139-189

8. Millan MJ (2014) On 'polypharmacy' and multi-target agents, complementary strategies for improving the treatment of depression: a comparative appraisal. International Journal of Neuropsychopharmacology 17: 1009-1037

9. Anighoro A, Bajorath J, Rastelli G (2014) Polypharmacology: Challenges and opportunities in drug discovery, J Med Chem 57: 7874-7887, Morphy R, Rankovic Z (2005) Designed Multiple Ligands. An Emerging Drug Discovery Paradigm. J Med Che 48: 6523-6543

10. Roth BL, Sheffler DJ, Kroeze WK (2004) Magic Shotguns versus Magic Bullets: Selectively Non-Selective Drugs for Mood Disorders and Schizophrenia. Nat Rev Drug Discovery 3: 353-359

11. Lipina TV, Palomo V, Gil C, Martinez A, Roder JC (2013) Dual Inhibitor of PDE7 and GSK-3-VP1.15 Acts as Antipsychotic and Cognitive Enhancer in C57BL/6J Mice. Neuropharmacology 64: 205-214

12. Lipina TV, Wang M, Liu F, Roder JC (2012) Synergistic Interactions between PDE4B and GSK-3: DISC1 Mutant Mice. Neuropharmacology 62: 1252-1262

13. Millan MJ (2006) Multi-target strategies for the improved treatment of depressive states: conceptual foundation and neuronal substrates, drug discovery and therapeutic application. Pharmacol Ther 110:135-370

14. Meltzer HY, Massey BW, Horiguchi M (2012) Serotonin receptors as targets for drugs useful to treat psychosis and cognitive impairment in schizophrenia. Curr Pharm Biotechnol 13:1572-1586

15. Quesseveur G, Nguyen HT, Gardier AM, Guiard BP (2012) 5-HT2 ligands in the treatment of anxiety and depression. Expert Opin Investig Drugs 21:1701-1725 
16. Youdim MBH, Buccafusco JJ (2005) Multi-Functional Drugs for Various CNS Targets in the Treatment of Neurodegenerative Disorders. Trends Pharmacol Sci 26: 27-35

17. Tahtouh T, Elkins JM, Filippakopoulos P, Soundararajan M, Burgy G, Durieu E, Cochet C, Schmid RS, Lo DC, Delhommel F, Oberholzer AE, Pearl LH, Carreaux F, Bazureau JP, Knapp S, Meijer L (2012) Selectivity, Cocrystal Structures, and Neuroprotective Properties of Leucettines, a Family of Protein Kinase Inhibitors Derived from the Marine Sponge Alkaloid Leucettamine, B J Med Chem 55: 9312-9330

18. Rosini M, Antonello A, Cavalli A, Bolognesi ML, Minarini A, Marucci G, Poggesi E, Leonardi A, Melchiorre C (2003) Prazosin-related compounds. Effect of transforming the piperazinylquinazoline moiety into an aminomethyltetrahydroacridine system on the affinity for $\alpha 1$-adrenoreceptors. J Med Chem 46: 4895-4903

19. Fang L, Appenroth D, Decker M, Kiehntopf M, Roegler C, Deufel T, Fleck C, Peng S, Zhang Y, Lehmann J (2008) Synthesis and biological evaluation of NO-donortacrine hybrids as hepatoprotective anti-Alzheimer drug candidates. J Med Chem 51: 713-716

20. Stosel A, Schlenk M, Hinz S, Kuppers P, Heer J, Gutschow M, Muller CE (2013) Dual targeting of adenosine A2A receptors and monoamine oxidase B by $4 \mathrm{H}-3,1-$ benzothiazin-4-ones. J Med Chem, 56: 4580-4596, Fang L, Kraus B, Lehmann J, Heilmann J, Zhang Y, Decker M (2008) Design and synthesis of tacrine-ferulic acid hybrids as multi-potent anti-Alzheimer drug candidates. Bioorg Med Lett 18: 29052909

21. Jiménez JJ, Mendes E, Galdeano C, Martins C, Silva DB; Marco-Contelles J, Carmo Carreiras M, Luque FJ, Ramsay RR (2014) Exploring the structural basis of the selective inhibition of monoamine oxidase A by dicarbonitrile aminoheterocycles: Role of Asn181 and Ile335 validated by spectroscopic and computational studies. Biochim Biophys Acta 1844: 389-397

22. Bautista-Aguileraa OM, Estebanb G, Bolea I, Nikolic K, Agbaba D, Moraleda I, Iriepa I, Samadi A, Soriano E, Unzeta M, Marco-Contelles J (2014) Design, synthesis, pharmacological evaluation, QSAR analysis, molecular modeling and ADMET of novel donepezil-indolyl hybrids as multipotent cholinesterase/monoamine oxidase inhibitors for the potential treatment of Alzheimer's disease. Eur J Med Chem 75: 82-95

23. Samadi A, Chioua M, Bolea I, de los Ríos C, Iriepa I, Moraleda I, Bastida A, Esteban G, Unzeta M, Gálvez E, Marco-Contelles J (2011) Synthesis, biological assessment and molecular modeling of new multipotent MAO and cholinesterase inhibitors as potential drugs for the treatment of Alzheimer's disease. Eur J Med Chem 46: 46654668

24. Bolea I, Juárez-Jiménez J, de los Ríos C, Chioua M, Pouplana R, Javier Luque F, Unzeta M, Marco-Contelles J, Samadi A (2011) Synthesis, Biological Evaluation, and Molecular Modeling of Donepezil and N-[(5-(Benzyloxy)-1-methyl-1H-indol-2yl)methyl]-Nmethylprop-2-yn-1-amine Hybrids as New Multipotent Cholinesterase/Monoamine Oxidase Inhibitors for the Treatment of Alzheimer's Disease. J Med Chem 54: 8251-8270 
25. Pérez V, Marco-Contelles J, Fernández-Álvarez E, Unzeta M (1999) Relevance of benzyloxy group in 2-indolyl methylamines in the selective MAO-B inhibition. Brit J Pharmacol 127: 869-876

26. Marco-Contelles J, Leon R, Rios C, Guglietta A, Terencio J, Lopez MG, Garcia AG, Villarroya M (2006) Novel Multipotent Tacrine-Dihydropyridine Hybrids with Improved Acetylcholinesterase Inhibitory and Neuroprotective Activities as Potential Drugs for the Treatment of Alzheimer's Disease. J Med Chem 49: No. 26

27. Marco-Contelles J, Leon R, Rios C, Samadi A, Bartolini M, Andrisano V, Huertas O, Barril X,; Luque FJ, Rodriguez-Franco MI, Lopez B, Lopez MG, Garcia AG, Carmo Carreiras M, Villarroya M (2009) Tacripyrines, the First Tacrine-Dihydropyridine Hybrids, as Multitarget-Directed Ligands for the Treatment of Alzheimer's Disease. J Med Chem 52: 2724-2732

28. Apelt J, Ligneau X, Pertz H, Arrang JM, Ganellin CR, Schwartz JC, Schunack W, Holger S (2002) Development of a new class of nonimidazole histamine H(3) receptor ligands with combined inhibitory histamine $\mathrm{N}$-methyltransferase activity. J Med Chem 45: 1128-1141

29. Petroianu G, Arafat K, Sasse BC, Stark H (2006) Multiple enzyme inhibitions by histamine $\mathrm{H} 3$ receptor antagonists as potential procognitive agents. Pharmazie 61: $179-182$

30. Grassmann S, Apelt J, Sippl W, Ligneau X, Pertz HH, Zhao YH, Arrang JM, Ganellin CR, Schwartz JC, Schunack W, Stark H (2003) Imidazole derivatives as a novel class of hybrid compounds with inhibitory histamine N-methyltransferase potencies and histamine H3 receptor affinities. Bioorg Med Chem 11: 2163-2174

31. Grassmann S, Apelt J, Ligneau X, Pertz HH, Arrang JM, Schwartz JC, Schunack W, Stark H (2004) Search for histamine H(3) receptor ligands with combined inhibitory potency at histamine $\mathrm{N}$-methyltransferase: omega-piperidinoalkanamine derivatives. Arch Pharm Med Chem 337: 533-545

32. Apelt J, Grassmann S, Ligneau X, Pertz HH, Ganellin CR, Arrang JM, Schwartz JC, Schunack W, Stark H (2005) Search for histamine H3 receptor antagonists with combined inhibitory potency at Ntau-methyltransferase: ether derivatives. Pharmazie 60: $97-106$

33. Ligneau X, Lin JS, Vanni-Mercier G, Jouvet M, Muir JL, Ganellin CR, Stark H, Elz S, Schunack W, Schwartz JC (1998) Neurochemical and Behavioural Effects of Ciproxifan, a Potent Histamine H3-Receptor Antagonist. J Pharmacol Exp Ther 287: 658-666

34. Sander K, Kottke T, Stark H (2008) Histamine H3 Receptor Antagonists Go to Clinics. Biol Pharm Bull 31: 2163-2181

35. Esbenshade TA, Browman KE, Bitner RS, Strakhova M, Cowart MD, Brioni JD (2008) The histamine $\mathrm{H} 3$ receptor: An attractive target for the treatment of cognitive disorders. Br J Pharmacol 154: 1166-1181

36. Di Giovanni G, Di Matteo V, Pierucci M, Esposito E (2008) Serotonin-dopamine interaction: electrophysiological evidence. Prog Brain Res 172: 45-71

37. Di Matteo V, Di Giovanni G, Pierucci M, Esposito E (2008) Serotonin control of central dopaminergic function: focus on in vivo microdialysis studies. Prog Brain Res 172: 7-44 
38. Carlsson M, Carlsson A (1990) Interactions between glutamatergic and monoaminergic systems within the basal ganglia - implications for schizophrenia and Parkinson 's disease. Trends Neurosci 13: 272-276,

39. Millan MJ (2005) N-Methyl-d-aspartate receptors as a target for improved antipsychotic agents: Novel insights and clinical perspectives. Psychopharmacology 179: $30-53$

40. Rogawski MA, Wenk GL (2003) The neuropharmacological basis for the use of memantine in the treatment of Alzheimer's disease. CNS Drug Rev 9: 275-308

41. Cummings JL, Morstorf T, Zhong K (2014) Alzheimer's disease drug-development pipeline: Few candidates, frequent failures. Alzheimers Res Ther 6: 37

42. Zheng H, Youdim MBH, Fridkin M. Site-activated multifunctional chelator with acetylcholinesterase and neuroprotective-neurorestorative moieties for Alzheimer's therapy. J Med Chem 52: 4095-4098

43. Cavalli A, Bolognesi ML, Minarini M, Rosini V, Tumiatti M, Recanatini C, Melchiorre C (2008) Multi-target-directed ligands to combat neurodegenerative diseases. J Med Chem 51: 347-372

44. Cannon EO, Bender A, Palmer DS, Mitchell JBO (2006) Chemoinformatics-Based Classification of Prohibited Substances Employed for Doping in Sport. J Chem Inf Model 5: 2369-2380

45. Cannon EO, Mitchell JBO (2006) Classifying the World Anti-Doping Agency's 2005 Prohibited List Using the Chemistry Development Kit Fingerprint. Lecture Notes in Bioinformatics 5: 173-182

46. Cannon EO, Nigsch F, Mitchell JBO (2008) Novel Hybrid Ultrafast Shape Descriptor Method for use in Virtual Screening. Chem Central J 5: 3

47. Paolini VG, Shapland RHB, Van Hoorn WP, Mason JS, Hopkins AL (2006) Global mapping of pharmacological space. Nat Biotechnol 5: 805-815

48. Bender A, Scheiber J, Glick M, Davies JW, Azzaoui K, Hamon J, Urban L, Whitebread S, Jenkins JL (2007) Analysis of pharmacology data and the prediction of adverse drug reactions and off-target effects from chemical structure. Chem Med Chem 5: 861-873

49. Nigsch F, Mitchell JBO (2008) Toxicological Relationships Between Proteins Obtained from Protein Target Predictions of Large Toxicity Databases. Toxicol Appl Pharmacol 5: 225-234

50. Nigsch F, Bender A, Jenkins JL, Mitchell JBO (2008) Ligand-Target Prediction using Winnow and Naive Bayesian Algorithms and the Implications of Overall Performance Statistics. J Chem Inf Model 5: 2313-2325

51. Keiser MJ, Setola V, Irwin JJ, Laggner C, Abbas AI, Hufeisen SJ, Jensen NH, Kuijer MB, Matos RC, Tran TB, Whaley R, Glennon RA, Hert J, Thomas KLH, Edwards DD, Shoichet BK, Roth BL (2009) Predicting new molecular targets for known drugs. Nature 2009, 5: 175-181

52. Niijima S, Yabuuchi H, Okuno Y (2011) Cross-Target View to Feature Selection: Identification of Molecular Interaction Features in Ligand-Target Space. J Chem Inf Model 5, 15-24

53. Lounkine E, Keiser MJ, Whitebread S, Mikhailov D, Hamon J, Jenkins JL, Lavan P, Weber E, Doak AK, Cote S, Shoichet BK, Urban L (2012) Large-scale prediction and testing of drug activity on side-effect targets. Nature 5: 361-367 
54. Perez-Nueno VI, Venkatraman V, Mavridis L, Ritchie DW (2012) Detecting Drug Promiscuity Using Gaussian Ensemble Screening. J Chem Inf Model 5: 1948-1961

55. Glen RC, Bender A, Arnby CH, Carlsson L, Boyer S, Smith J (2006) Circular Fingerprints: Flexible molecular descriptors with applications from physical chemistry to ADME. IDrugs 9: 199-204

56. Mavridis L, Mitchell JBO (2013) Predicting the protein targets for athletic performance-enhancing substances. J Cheminform 5: 31

57. Gaulton A, Bellis LJ, Bento PA, Chambers J, Davies M, Hersey A, Light Y, McGlinchey S, Michalovich D, Al-Lazikani B, Overington JP (2012) ChEMBL: a large-scale bioactivity database for drug discovery. Nucleic Acids Res 5: D1100D1107

58. Knox C, Law V, Jewison T, Liu P, Ly S, Frolkis A, Pon A, Banco K, Mak C, Neveu V, Djoumbou Y, Eisner R, Guo AC, Whishart DS (2011) DrugBank 3.0: a comprehensive resource for 'omics' research on drugs. Nucleic Acids Res 5: D1035D1041

59. Mavridis L, Nath N, Mitchell JBO (2013) PFClust: A Novel Parameter Free Clustering Algorithm. BMC Bioinformatics 14: 213

60. Rogers DJ, Tanimoto TT (1960) A Computer Program for Classifying Plants. Science 5: $1115-1118$

61. Parzen E (1962) On Estimation of a Probability Density Function and Mode. Ann Math Statist 5: 1065-1076

62. Rosenblatt M (1956) Remarks on Some Nonparametric Estimates of a Density Function. Ann Math Statist 5: 832-837

63. Matthews BW (1975) Comparison of the predicted and observed secondary structure of T4 phage lysozyme. Biochim Biophys Acta 5: 442-451

64. Hamacher A, Weigt M, Wiese M, Hoefgen B, Lehmann J, Kassack MU (2006) Dibenzazecine compounds with a novel dopamine/5HT2A receptor profile and 3DQSAR analysis, BMC Pharmacology 6: No 11

65. ChemAxon MarvinSketch 5.5.1.0 program (2011) Budapest, Hungary www.chemaxon.com/products.html

66. Froese Fischer CF (1977) The Hartree-Fock Method for Atoms: A Numerical Approach. John Wiley and Sons, New York

67. Gaussian 98 (Revision A.7) Frisch MJ et al (1998) Gaussian Inc., Pittsburgh PA

68. Pentacle, Version 1.0.6., (2009) Molecular Discovery Ltd, Perugia, Italy http://www.moldiscovery.com/soft_pentacle.php

69. Eriksson L, Johansson E, Kettaneh-Wold N, Trygg J, Wikstrom C, Wold S. (Eds.) (2001) Multi-and Megavariate Data Analysis. Basic Principles and Applications I, 2nd ed, Umetrics Academy, Umeå

70. Tropsha A (2010) Best Practices for QSAR Model Development, Validation, and Exploitation. Mol Inf 29: 476-488

71. Cheng YC, Prusoff WH (1973) Relationship between the inhibition constant $\left(\mathrm{K}_{\mathrm{i}}\right)$ and the concentration of inhibitor which causes 50 per cent inhibition $\left(\mathrm{IC}_{50}\right)$ of an enzymatic reaction. Biochem Pharmacol 22: 3099-3108

72. Scatchard G (1949) The attraction of proteins for small molecules and ions. Ann NY Acad Sci 51: 660-672 
73. Schlegel JR, Peroutka SJ (1986) Nucleotide interactions with 5-HT ${ }_{1 \mathrm{~A}}$ binding sites directly labeled by $\left[{ }^{3} \mathrm{H}\right]-8$-hydroxy-2-(di-n-propylamino)tetralin $\left(\left[{ }^{3} \mathrm{H}\right]-8-\mathrm{OH}-\mathrm{DPAT}\right)$. Biochem Pharmacol 35: 1943-1949

74. Herndon JL, Ismaiel A, Ingher SP, Teitler M, Glennon RA (1992) Ketanserin analogues: structure-affinity relationships for $5-\mathrm{HT}_{2}$ and $5-\mathrm{HT}_{1 \mathrm{C}}$ serotonin receptor binding. J Med Chem 35: 4903-4910

75. Buhot MC, Martin S, Segu L (2000) Role of serotonin in memory impairment. Ann Med 32: 210-21.

76. Roth BL, Hanizavareh SM, Blum AE (2004) Serotonin receptors represent highly favorable molecular targets for cognitive enhancement in schizophrenia and other disorders. Psychopharmacology (Berl) 174: 17-24

77. Gray JA, Roth BL (2007) The pipeline and future of drug development in schizophrenia. Mol Psychiatry12:904-922

78. Nakamura M, Ogasa M, Guarino J, Phillips D, Severs J, Cucchiaro J, Loebel, A (2009) Lurasidone in the treatment of acute schizophrenia: a double-blind, placebocontrolled trial. J Clin Psychiatry 70:829-836

79. Patat A, Parks V, Raje S, Plotka A, Dietrich B (2005) Age-gender study of SRA-333, a novel 5-HT1A antagonist. Clin Pharmacol Ther 77: P29-P

80. Pitsikas N, Tsitsirigou S, Zisopoulou S, Sakellaridis N (2005) The 5-HT1A receptor and recognition memory. Possible modulation of its behavioral effects by the nitrergic system. Behav Brain Res159: 287-293

81. Schechter LE, Smith DL, Rosenzweig-Lipson S, Sukoff SJ, Dawson LA, Marquis K, Jones D, Piesla M, Andree T, Nawoschik S, Harder JA, Womack MD, Buccafusco J, Terry AV, Hoebel B, Rada P, Kelly M, Abou-Gharbia M., Barrett JE, Childers W (2005) Lecozotan (SRA-333): a selective serotonin 1A receptor antagonist that enhances the stimulated release of glutamate and acetylcholine in the hippocampus and possesses cognitive-enhancing properties. J Pharmacol Exp Ther 314: 12741289

82. Ballanger B, Klinger H, Eche J, Lerond J, Vallet AE, Le Bars D, Tremblay L, Sgambato-Faure V, Broussolle E, Thobois S (2012) Role of serotonergic 1A receptor dysfunction in depression associated with Parkinson's disease. Movement Disorders 27: 84-89

83. Wallace TL, Ballard TM, Pouzet B, Riedel WJ, Wettstein JG (2011) Drug targets for cognitive enhancement in neuropsychiatric disorders. Pharmacol Biochem Be 99: $130-145$

84. Terry AV, Hoebel B, Rada P, Kelly M, Abou-Gharbia M., Barrett JE, Childers W (2005) Lecozotan (SRA-333): a selective serotonin 1A receptor antagonist that enhances the stimulated release of glutamate and acetylcholine in the hippocampus and possesses cognitive-enhancing properties. J Pharmacol Exp Ther 314: 1274-1289

85. Terry Jr AV, Buccafusco JJ, Bartoszyk GD (2005) Selective serotonin 5-HT2A receptor antagonist EMD 281014 improves delayed matching performance in young and aged rhesus monkeys. Psychopharmacology (Berl) 179:725-732

86. Onogi H, Ishigaki S, Nakagawasai O, Arai-Kato Y, Arai Y, Watanabe H, Miyamoto A, Tan-No K, Tadano T (2009) Influence of memantine on brain monoaminergic neurotransmission parameters in mice: Neurochemical and behavioral study. Biol Pharm Bull 32: 850—855, 
87. Reisberg B, Doody R, Stöffler A, Schmitt F, Ferris S, Möbius HJ (2006) A 24-week open-label extension study of memantine in moderate to severe alzheimer disease. Arch Neurology 63: 49-54

88. Kim HS, Park IS, Park WK (1998) NMDA receptor antagonists enhance 5-HT2 receptor-mediated behavior, head-twitch response, in mice. Life Sci. 63, 2305-2311

89. Nakagawasai O, Arai Y, Satoh SE., Satoh N, Neda M, Hozumi M, Oka R, Hiraga H, Tadano T (2004) Monoamine Oxidase and Head-Twitch Response in Mice Mechanisms of $\alpha$-Methylated Substrate Derivatives. Neurotoxicology 25: 223-232

90. Raddatz R, Tao M, Hudkins RL (2010) Histamine H3 antagonists for treatment of cognitive deficits in CNS diseases. Curr Top Med Chem 10: 153-169 


\section{List of Tables}

Table 1. Compounds examined in this study [21-29].

Table 2. Experimental validation of the top ranked targets (PR-Scores $\leq 0.10)$ for the MAO/ChE inhibitors class (44-100). a) PR-Scores are derived by applying the cheminformatic methodology against the refined ChEMBL dataset.

Table 3. Experimental and 3D-QSAR validation of the top ranked targets for the MAO/ChE inhibitors class (44-100). a) PR-Scores are derived by applying the cheminformatic methodology against the refined ChEMBL dataset. b) $p K i=\log (1 / \mathrm{Ki})$, $\mathrm{Ki}[\mathrm{M}]$, c) $\mathrm{Ki}\left(5-\mathrm{HT}_{1 \mathrm{a}} \mathrm{R}\right)=1.08 \times 10^{-7} \pm 0,04 \mathrm{M}, \mathrm{IC}_{50}\left(5-\mathrm{HT}_{1 \mathrm{a}} \mathrm{R}\right)=2.40 \times 10^{-7} \pm 0,10 \mathrm{M}$, $\mathrm{Ki}\left(5-\mathrm{HT}_{2 \mathrm{a}} \mathrm{R}\right)=1.42 \times 10^{-8} \pm 0.57 \mathrm{M}, \mathrm{IC}_{50}\left(5-\mathrm{HT}_{2 \mathrm{a}} \mathrm{R}\right)=1.92 \times 10^{-8} \pm 0.77 \mathrm{M}$.

Table 4. Experimental validation of the top ranked targets (PR-Scores $\leq 0.10)$ for the $\mathrm{H}_{3} \mathrm{R} / \mathrm{HMT} / \mathrm{ChE}$ ligands (101/1-Hetero-134/34-Hetero). a) PR-Scores are derived by applying the cheminformatic methodology against the refined ChEMBL dataset.

Table 5. List of the top ranked targets predictions (PR-Scores $\leq 0.10)$ for the $\mathrm{H}_{3} \mathrm{R} / \mathrm{HMT} / \mathrm{ChE}$ ligands (101/1-Hetero-134/34-Hetero). a) PR-Scores are derived by applying the cheminformatic methodology against the refined ChEMBL dataset. 


\begin{tabular}{|c|c|c|}
\hline ID & Chemical scaffold & Experimentally determined activity on Target \\
\hline $\mathbf{1 - 1 7}$ & $\begin{array}{c}\text { carbonitrile, } \\
\text { aminoheterocycles }\end{array}$ & MAO-A, MAO-B [7] \\
\hline $\mathbf{1 8 - 7 7}$, & acetylene, indol, piperidine & MAO-A, MAO-B, AChE, BuChE [8-11] \\
\hline $\mathbf{7 9 - 8 5}$ & pyridine & AChE, BuChE $[12,13]$ \\
\hline $\mathbf{7 8 , 8 6 - 1 0 0}$ & quinoline, piperidine & $\mathrm{H}_{3} \mathrm{R}, \mathrm{HMT}$, \\
& & $\mathrm{AChE} / \mathrm{BuChE}(\mathrm{ID}: 109,128,131,133-134)[14,15]$ \\
\hline
\end{tabular}

Table 1. Compounds examined in this study [21-29]. 


\begin{tabular}{|c|c|c|c|c|c|}
\hline ID & Compound & Target (ChEMBL ID) & PR-Score $^{a}$ & Experimental - Ki [nM] & Experimental $\mathrm{IC}_{50}[\mathrm{nM}]$ \\
\hline \multirow[t]{2}{*}{45} & FA-97 & MAO-B (2993) & 0.00712 & $2.9[11]$ & \\
\hline & & MAO-A (3358) & 0.06270 & $18.8[11]$ & \\
\hline \multirow[t]{2}{*}{48} & FA-66 & MAO-B (2993) & 0.01187 & $2.4[11]$ & \\
\hline & & MAO-A (3358) & 0.06659 & $5.4[11]$ & \\
\hline \multirow[t]{2}{*}{52} & FA-65 & MAO-B (2993) & 0.00194 & $9.4[11]$ & \\
\hline & & MAO-A (3358) & 0.04900 & $18.0[11]$ & \\
\hline \multirow[t]{2}{*}{54} & FA-67 & MAO-B (2993) & 0.02568 & $1.2[11]$ & \\
\hline & & MAO-A (3358) & 0.07348 & $26.5[11]$ & \\
\hline 55 & FA-73 & MAO-B (2993) & 0.00009 & $0.75[11]$ & \\
\hline \multirow[t]{2}{*}{56} & Donepezil & AChE(4768) & 0.00061 & $6.7[10]$ & \\
\hline & & BuChE (5077) & 0.00001 & $7400[10]$ & \\
\hline \multirow[t]{3}{*}{58} & DonzD-4 & MAO-A (3254) & 0.04951 & & $6.7[10]$ \\
\hline & & MAO-B (2993) & 0.01214 & & $130[10]$ \\
\hline & & AChE (220) & 0.08021 & $420[10]$ & \\
\hline \multirow[t]{3}{*}{59} & DonzD-5 & MAO-A (3254) & 0.05683 & & $5.2[10]$ \\
\hline & & MAO-B (2993) & 0.01517 & & $43[10]$ \\
\hline & & AChE (220) & 0.09698 & $350[10]$ & \\
\hline \multirow[t]{3}{*}{59} & DonzD-6 & MAO-A (3254) & 0.06466 & & $10[10]$ \\
\hline & & MAO-B (2993) & 0.01864 & & $2700[10]$ \\
\hline & & AChE (220) & 0.07038 & $260[10]$ & \\
\hline \multirow[t]{2}{*}{78} & Tacrine & AChE (3198) & 0.00003 & 105 [15] & \\
\hline & & BuChE (3403) & 0.00368 & 64 [15] & \\
\hline 93 & TP-8 & AChE (220) & 0.02822 & & $71[13]$ \\
\hline 95 & TP-10 & AChE (220) & 0.02542 & & $58[13]$ \\
\hline 98 & TP-12 & AChE (220) & 0.02580 & & $45[13]$ \\
\hline
\end{tabular}

Table 2. Experimental validation of the top ranked targets (PR-Scores $\leq 0.10)$ for the MAO/ChE inhibitors class (44-100). a) PR-Scores are derived by applying the cheminformatic methodology against the refined ChEMBL dataset. 


\begin{tabular}{|c|c|c|c|c|}
\hline ID & Compound & Target (ChEMBL ID) & PR-Score ${ }^{a}$ & $\begin{array}{c}\text { 3D-QSAR predicted }-p K i^{b} \text { or } \\
\text { Experimental-pKi }{ }^{c}\end{array}$ \\
\hline 31 & PF96-Donz-D8 & $\mathrm{H}_{3} \mathrm{R}(264)$ & 0.07922 & $9.509^{b}$ \\
\hline 33 & PF96-Donz-D10 & $\mathrm{H}_{3} \mathrm{R}(264)$ & 0.11912 & $10.137^{b}$ \\
\hline 34 & PF96-Donz-D11 & $\mathrm{H}_{3} \mathrm{R}$ & 0.05243 & $9.001^{b}$ \\
\hline 36 & PF96-Donz-D13 & $\mathrm{H}_{3} \mathrm{R}(264)$ & 0.09145 & $10.472^{b}$ \\
\hline 57 & DonzD-3 & $5-\mathrm{HT}_{2 \mathrm{a}} \mathrm{R}(322)$ & 0.14887 & $7.999^{b}$ \\
\hline 58 & DonzD-4 & $5-\mathrm{HT}_{2 \mathrm{a}} \mathrm{R}(322)$ & 0.13293 & $7.057^{b}$ \\
\hline 59 & DonzD-5 & $5-\mathrm{HT}_{2 \mathrm{a}} \mathrm{R}(322)$ & 0.14436 & $7.056^{\mathrm{b}}$ \\
\hline \multirow[t]{2}{*}{60} & DonzD-6 & $5-\mathrm{HT}_{2 \mathrm{a}} \mathrm{R}(322)$ & 0.15002 & $7.522^{b}$ \\
\hline & & $\mathrm{H}_{3} \mathrm{R}(264)$ & 0.14232 & $8.643^{b}$ \\
\hline \multirow[t]{2}{*}{62} & DonzD-8 & $D_{1} R(265)$ & 0.16686 & $6.928^{b}$ \\
\hline & & $\mathrm{H}_{3} \mathrm{R}$ (5299) & 0.13534 & $9.646^{\mathrm{b}}$ \\
\hline \multirow[t]{4}{*}{63} & DonzD-9 & $5-\mathrm{HT}_{2 \mathrm{a}} \mathrm{R}(322)$ & 0.11140 & $6.907^{b}$ \\
\hline & & $D_{1} R(265)$ & 0.09508 & $6.903^{b}$ \\
\hline & & $\mathrm{D}_{2} \mathrm{R}(217)$ & 0.07044 & $7.647^{b}$ \\
\hline & & $\mathrm{H}_{3} \mathrm{R}(264)$ & 0.07044 & $10.105^{b}$ \\
\hline 67 & MBA-50 & $D_{1} R(265)$ & 0.16648 & $6.448^{b}$ \\
\hline 68 & MBA-71 & $\mathrm{H}_{3} \mathrm{R}(4124)$ & 0.10730 & $8.746^{b}$ \\
\hline 69 & MBA-72 & $5-\mathrm{HT}_{2 \mathrm{a}} \mathrm{R}(322)$ & 0.10140 & $7.974^{b}$ \\
\hline 70 & MBA-73 & $\mathrm{D} 1 \mathrm{R}(265)$ & 0.12300 & $6.079^{b}$ \\
\hline \multirow[t]{3}{*}{71} & MBA-VEG8 & $5-\mathrm{HT}_{1 \mathrm{a}} \mathrm{R}(273)$ & 0.01827 & $6.967^{c}$ \\
\hline & & $5-\mathrm{HT}_{2 \mathrm{a}} \mathrm{R}(322)$ & 0.02139 & $7.848^{c}$ \\
\hline & & $\mathrm{D}_{1} \mathrm{R}(265)$ & 0.01073 & $6.580^{b}$ \\
\hline 82 & TC4-MBA-91 & $5-\mathrm{HT}_{2 \mathrm{a}} \mathrm{R}(322)$ & 0.10597 & $7.566^{b}$ \\
\hline 83 & TC5-MBA-98F1 & $5-\mathrm{HT}_{2 \mathrm{a}} \mathrm{R}(322)$ & 0.13397 & $7.360^{b}$ \\
\hline 84 & TC-MBA-98F2 & $5-\mathrm{HT}_{2 \mathrm{a}} \mathrm{R}(322)$ & 0.13397 & $8.632^{b}$ \\
\hline 85 & TC7-MBA-101 & $5-\mathrm{HT}_{2 \mathrm{a}} \mathrm{R}(322)$ & 0.12105 & $8.027^{b}$ \\
\hline
\end{tabular}

Table 3. Experimental and 3D-QSAR validation of the top ranked targets for the MAO/ChE inhibitors class (44-100). a) PR-Scores are derived by applying the cheminformatic methodology against the refined ChEMBL dataset. b) $p K i=\log (1 / \mathrm{Ki}), K i$ $[\mathrm{M}]$, c) $K i\left(5-\mathrm{HT}_{1 \mathrm{a}} \mathrm{R}\right)=1.08 \times 10^{-7} \pm 0,04 \mathrm{M}, \mathrm{IC}_{50}\left(5-\mathrm{HT}_{1 \mathrm{a}} \mathrm{R}\right)=2.40 \times 10^{-7} \pm 0,10 \mathrm{M}$, $K i\left(5-\mathrm{HT}_{2 \mathrm{a}} \mathrm{R}\right)=1.42 \times 10^{-8} \pm 0.57 \mathrm{M}, \mathrm{IC}_{50}\left(5-\mathrm{HT}_{2 \mathrm{a}} \mathrm{R}\right)=1.92 \times 10^{-8} \pm 0.77 \mathrm{M}$. 


\begin{tabular}{|c|c|c|c|c|}
\hline ID & Compound & Target (ChEMBL ID) & PR-Score ${ }^{a}$ & E-Value \\
\hline \multirow[t]{2}{*}{106} & 6-Hetero & HMT (3241) & 0.01022 & $\mathrm{IC}_{50}=16 \mathrm{nM}[14]$ \\
\hline & & $\mathrm{H}_{3} \mathrm{R}(264)$ & 0.01998 & $\mathrm{Ki}=411 \mathrm{nM}[14]$ \\
\hline \multirow[t]{2}{*}{107} & 7-Hetero & HMT (3241) & 0.00887 & $\mathrm{IC}_{50}=49 \mathrm{nM}[14]$ \\
\hline & & $\mathrm{H}_{3} \mathrm{R}(264)$ & 0.01514 & $\mathrm{Ki}=1130 \mathrm{nM}[14]$ \\
\hline \multirow[t]{2}{*}{108} & 8-Hetero & HMT (3241) & 0.00704 & $\mathrm{IC}_{50}=590 \mathrm{nM}[14]$ \\
\hline & & $\mathrm{H}_{3} \mathrm{R}(264)$ & 0.00795 & $\mathrm{Ki}=70 \mathrm{nM}[14]$ \\
\hline \multirow[t]{4}{*}{109} & 9-Hetero & AChE (4078) & 0.00036 & $\mathrm{Ki}=40.0 \mu \mathrm{M}[15]$ \\
\hline & & BuChE (5077) & 0.00031 & $\mathrm{Ki}=25.4 \mu \mathrm{M}[15]$ \\
\hline & & $\operatorname{HMT}(3241)$ & 0.01466 & $\mathrm{IC}_{50}=45 \mathrm{nM}[14]$ \\
\hline & & $\mathrm{H}_{3} \mathrm{R}(264)$ & 0.01795 & $\mathrm{Ki}=34 \mathrm{nM}[14]$ \\
\hline \multirow[t]{2}{*}{118} & 18-Hetero & $\operatorname{HMT}(3241)$ & 0.00626 & $\mathrm{IC}_{50}=340 \mathrm{nM}[14]$ \\
\hline & & $\mathrm{H}_{3} \mathrm{R}(264)$ & 0.00965 & $\mathrm{Ki}=3.6 \mathrm{nM}[14]$ \\
\hline \multirow[t]{2}{*}{129} & 29-Hetero & HMT (3241) & 0.00046 & $\mathrm{IC}_{50}=420 \mathrm{nM}[14]$ \\
\hline & & $\mathrm{H}_{3} \mathrm{R}(264)$ & 0.01789 & $\mathrm{Ki}=0.53 \mathrm{nM}[14]$ \\
\hline \multirow[t]{2}{*}{130} & 30-Hetero & HMT (3241) & 0.00067 & $\mathrm{IC}_{50}=31 \mathrm{nM}[14]$ \\
\hline & & $\mathrm{H}_{3} \mathrm{R}(264)$ & 0.01424 & $\mathrm{Ki}=0.75 \mathrm{nM}[14]$ \\
\hline \multirow[t]{4}{*}{131} & 31-Hetero & AChE (4078) & 0.00789 & $\mathrm{IC}_{50}=8.6 \mathrm{nM}[15]$ \\
\hline & & BuChE (5077) & 0.00750 & $\mathrm{IC}_{50}=10.0 \mathrm{nM}[15]$ \\
\hline & & HMT (3241) & 0.01535 & $\mathrm{IC}_{50}=95 \mathrm{nM}[14]$ \\
\hline & & $\mathrm{H}_{3} \mathrm{R}(264)$ & 0.07511 & $\mathrm{Ki}=1.4 \mathrm{nM}[14]$ \\
\hline \multirow[t]{4}{*}{133} & 33-Hetero & AChE (4078) & 0.00235 & $\mathrm{IC}_{50}=3.1 \mathrm{nM}[15]$ \\
\hline & & BuChE (5077) & 0.00297 & $\mathrm{IC}_{50}=9.4 \mathrm{nM}[15]$ \\
\hline & & HMT (3241) & 0.01691 & $\mathrm{IC}_{50}=48 \mathrm{nM}[14]$ \\
\hline & & $\mathrm{H}_{3} \mathrm{R}(264)$ & 0.03693 & $\mathrm{Ki}=1.8 \mathrm{nM}[14]$ \\
\hline
\end{tabular}

Table 4. Experimental validation of the top ranked targets (PR-Scores $\leq 0.10)$ for the $\mathrm{H}_{3} \mathrm{R} / \mathrm{HMT} / \mathrm{ChE}$ ligands (101/1-Hetero-134/34-Hetero). a) PR-Scores are derived by applying the cheminformatic methodology against the refined ChEMBL dataset. 


\begin{tabular}{|c|c|c|c|c|}
\hline ID & Compound & Target (ChEMBL ID) & PR-Score ${ }^{a}$ & 3D-QSAR predicted $-p K i^{b}$ \\
\hline \multirow[t]{3}{*}{102} & 2-Hetero & $5-\mathrm{HT}_{2 \mathrm{a}} \mathrm{R}(322)$ & 0.04929 & $6.488^{b}$ \\
\hline & & $\mathrm{D}_{2} \mathrm{R}(339)$ & 0.06299 & $6.715^{b}$ \\
\hline & & Serotonin transporter (313) & 0.06639 & - \\
\hline 106 & 6-Hetero & $\mathrm{H}_{1} \mathrm{R}(231)$ & 0.05799 & - \\
\hline 107 & 7-Hetero & $\mathrm{H}_{1} \mathrm{R}(231)$ & 0.04352 & - \\
\hline 108 & 8-Hetero & $\mathrm{H}_{1} \mathrm{R}(231)$ & 0.02623 & - \\
\hline 111 & 11-Hetero & $\mathrm{H}_{1} \mathrm{R}(231)$ & 0.01920 & - \\
\hline 118 & 18-Hetero & $\mathrm{H}_{1} \mathrm{R}(231)$ & 0.02817 & - \\
\hline 119 & 19-Hetero & $\mathrm{H}_{1} \mathrm{R}(231)$ & 0.00283 & - \\
\hline 130 & 30-Hetero & $\mathrm{H}_{1} \mathrm{R}(231)$ & 0.04670 & - \\
\hline \multirow[t]{2}{*}{131} & 31-Hetero & Beta amyloid A4 protein (2487) & 0.01596 & \\
\hline & & Glutamate [NMDA]R subunit zeta-1 (2015) & 0.00374 & \\
\hline \multirow[t]{3}{*}{132} & 32-Hetero & $\mathrm{H}_{1} \mathrm{R}(231)$ & 0.00760 & - \\
\hline & & Beta amyloid A4 protein (2487) & 0.00813 & - \\
\hline & & Glutamate [NMDA]R subunit zeta-1 (2015) & 0.00143 & \\
\hline \multirow[t]{2}{*}{133} & 33-Hetero & Beta amyloid A4 protein (2487) & 0.00382 & - \\
\hline & & Glutamate [NMDA]R subunit zeta-1 (2015) & 0.00143 & \\
\hline
\end{tabular}

Table 5. List of the top ranked targets predictions (PR-Scores $\leq 0.10)$ for the $\mathrm{H}_{3} \mathrm{R} / \mathrm{HMT} / \mathrm{ChE}$ ligands (101/1-Hetero-134/34-Hetero). a) PR-Scores are derived by applying the cheminformatic methodology against the refined ChEMBL dataset. b) $p K i=$ $\log (1 / \mathrm{Ki}), \mathrm{Ki}[\mathrm{M}]$. 


\section{List of Figures}

Figure 1. General structural formulas of the examined compounds 1-134 [21-29]. Stereocenters are indicated with a star $(*)$.

Figure 2. Target prediction methodology applied for a query compound (1-134) using the refined ChEMBL dataset.

Figure 3. General structural formula of the indol derivatives used for 3D-QSAR $\left(D_{1} R\right)$, 3D-QSAR $\left(\mathrm{D}_{2} \mathrm{R}\right)$, and 3D-QSAR(5-HT $\left.2 \mathrm{a}\right)$ modeling.

Figure 4. Ligand-target associations for all examined compounds (1-134), obtained by querying the 134 compounds against the refined ChEMBL dataset.

Figure 5. Target prediction for 63/Donz-D9.

Figure 6. Target prediction for 71/MBA-VEG8.

Figure 7. Concentration-response curves of compound 71/MBA-VEG8 in in vitro assays for $5-\mathrm{HT}_{1 \mathrm{a}}\left(\mathrm{IC}_{50} 2.40 \times 10^{-7} \pm 0.10\right)(\mathbf{A})$ and for $5-\mathrm{HT}_{2 \mathrm{a}}\left(\mathrm{IC}_{50} 1.92 \times 10^{-8} \pm 0.77\right)(\mathbf{B})$ receptor binding. The curves were generated by non-linear regression to determine the $\mathrm{IC}_{50}$ values. Data points are the mean $\pm \mathrm{SD}$ of triplicate values as described in Methods.

Figure 8. Chemical scaffolds of 63/Donz-D9, 71/MBA-VEG8, 102/2-Hetero, haloperidol, and clozapine. 


\section{List of Supplementary Tables}

Supplementary Table 1. Ligand-target associations for all examined compounds (1134), obtained by querying the 134 compounds against the refined ChEMBL dataset.

Supplementary Table 2. Ligand-pharmacological group associations for all examined compounds (1-134), obtained by querying the 134 compounds against the refined DrugBank dataset. 


\section{List of Supplementary Figures}

Supplementary Figure 1. Ligand-pharmacological group associations for all examined compounds (1-134), obtained by querying the 134 compounds against the refined DrugBank dataset. 


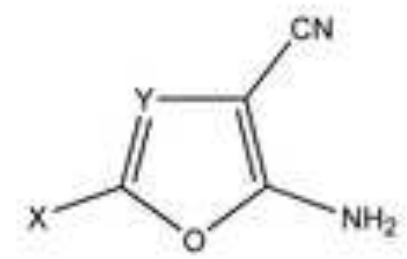

Cyano-derivatives (ID: 1-17) target; MAO-A/B

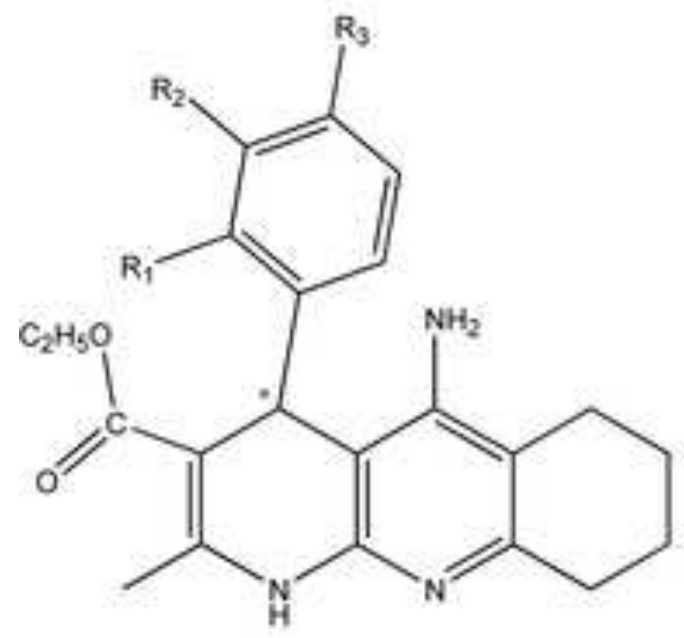

Pyridine derivatives (ID: 86-100) target: $\mathrm{ChE}$

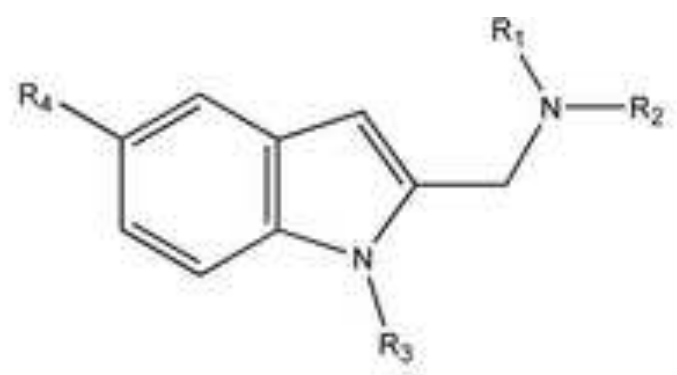

Indol-derivatives (ID: 44-55) target: $\mathrm{MAO}-\mathrm{A} / \mathrm{B}$

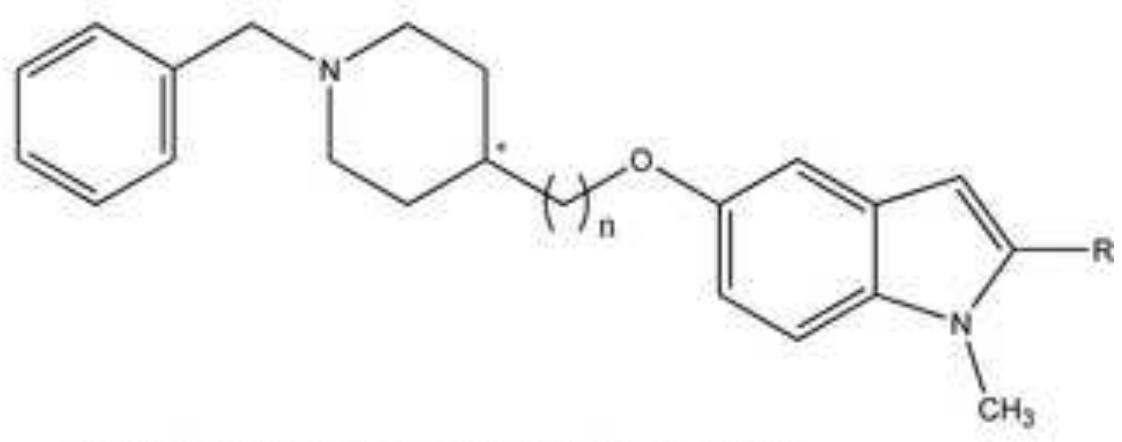

Indol/Piperidine derivatives (ID): $18-43,56-85$ ) target: MAO/ChE<smiles>[R]c1ccc2nc([R3])c([R2])c(N([R])[X]N3CCCCC3)c2c1</smiles>

Quinoline/Piperidine derivatives (ID: 101-134) target: H3R/HMTChE 


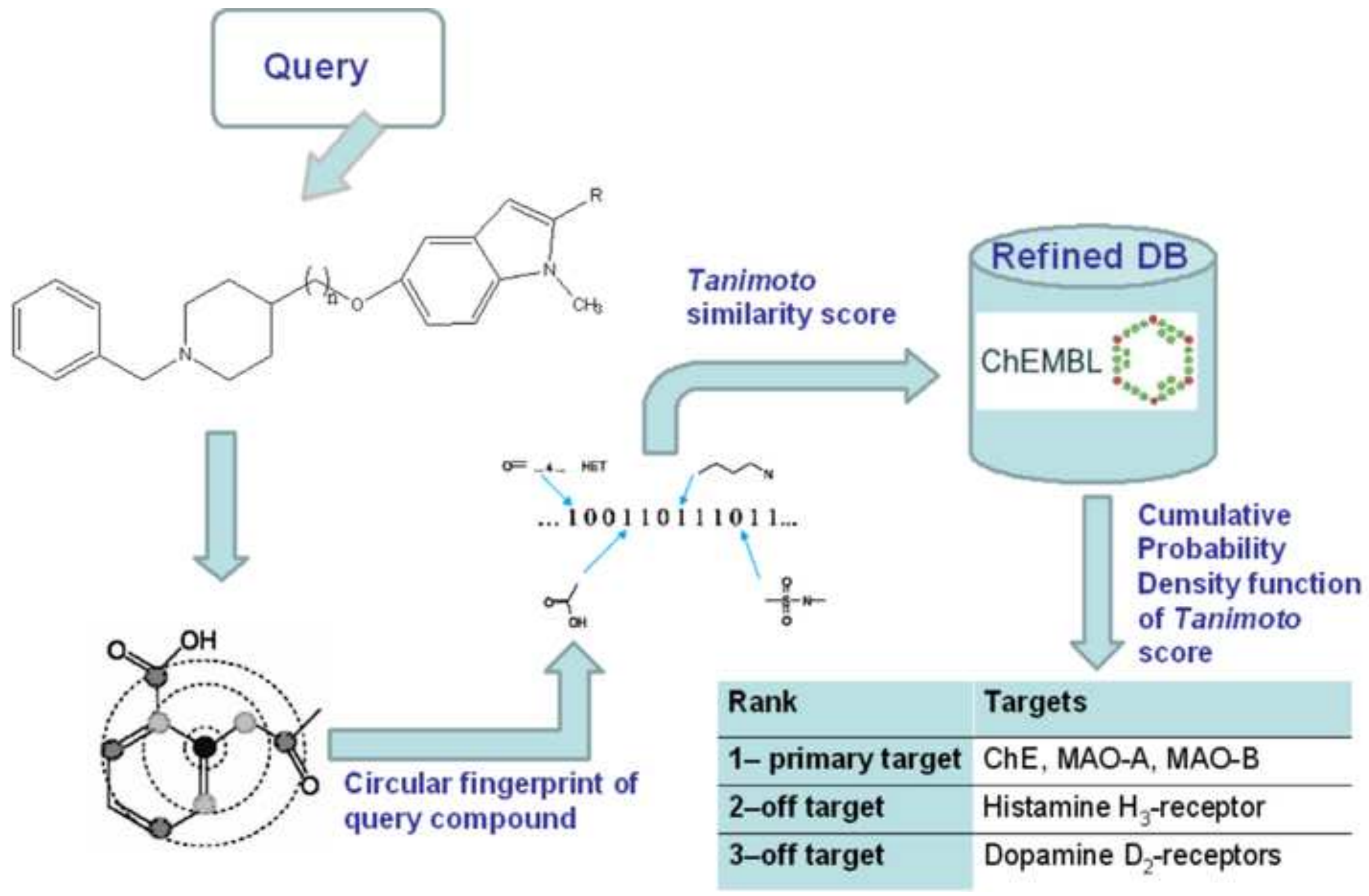




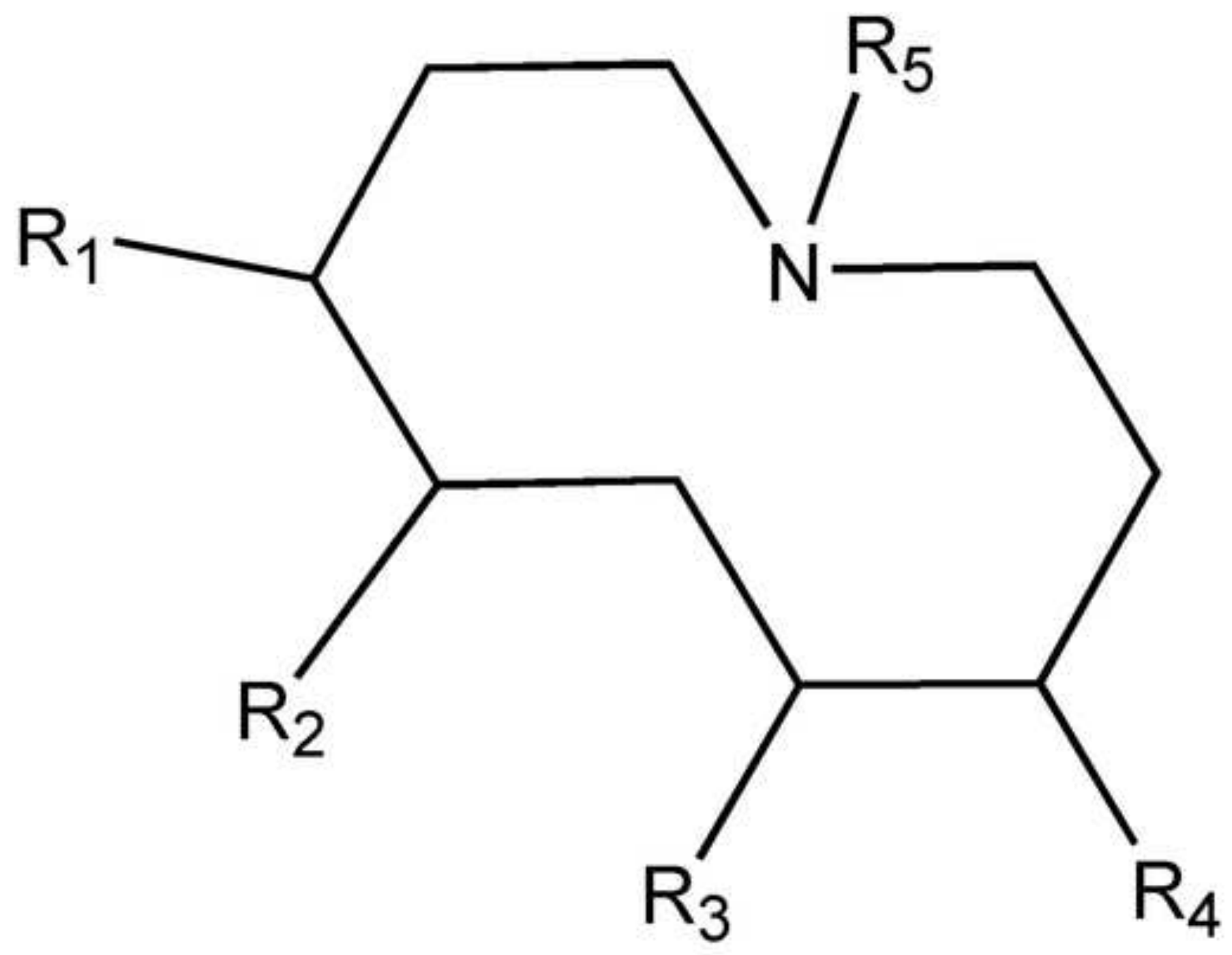

$D_{1} R / D_{2} R / 5-H T_{2 a} R$ ligands 

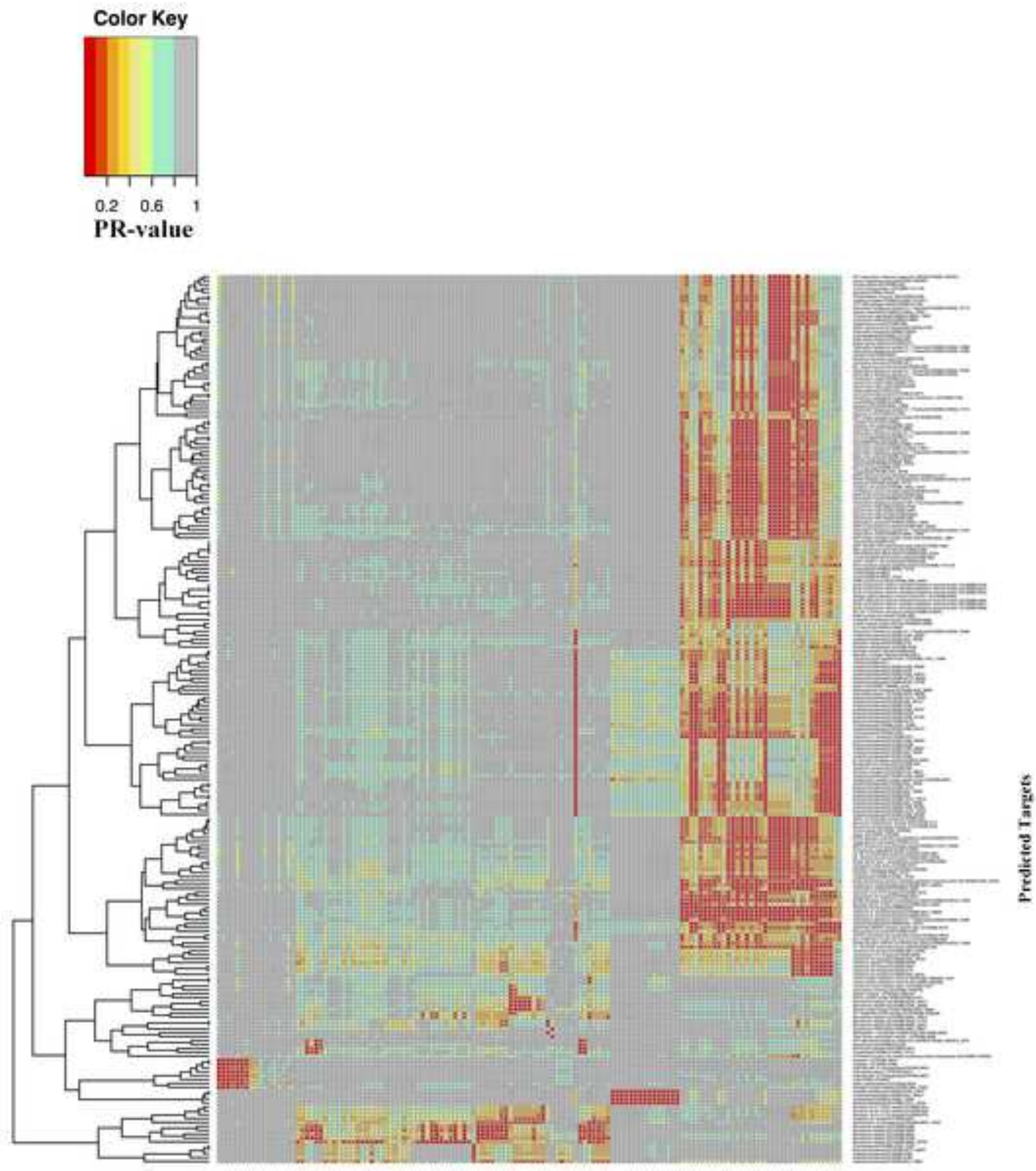

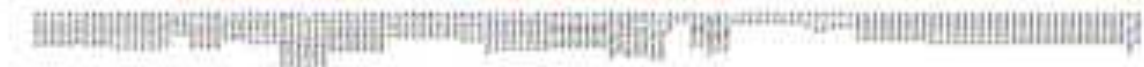
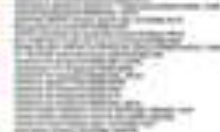

Lit
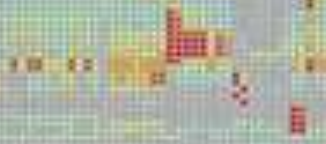

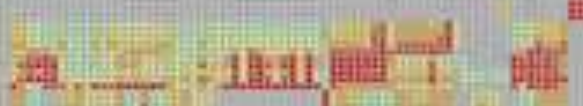

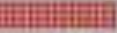

ID: 1.17

ID: $18-43$

ID: 4+-55 ID: 56-85

ID: $86-100$

II): 101-134

Query Compounds (ID: 1-134) 


\section{Predicting activities for a molecule-ID: 1-100}

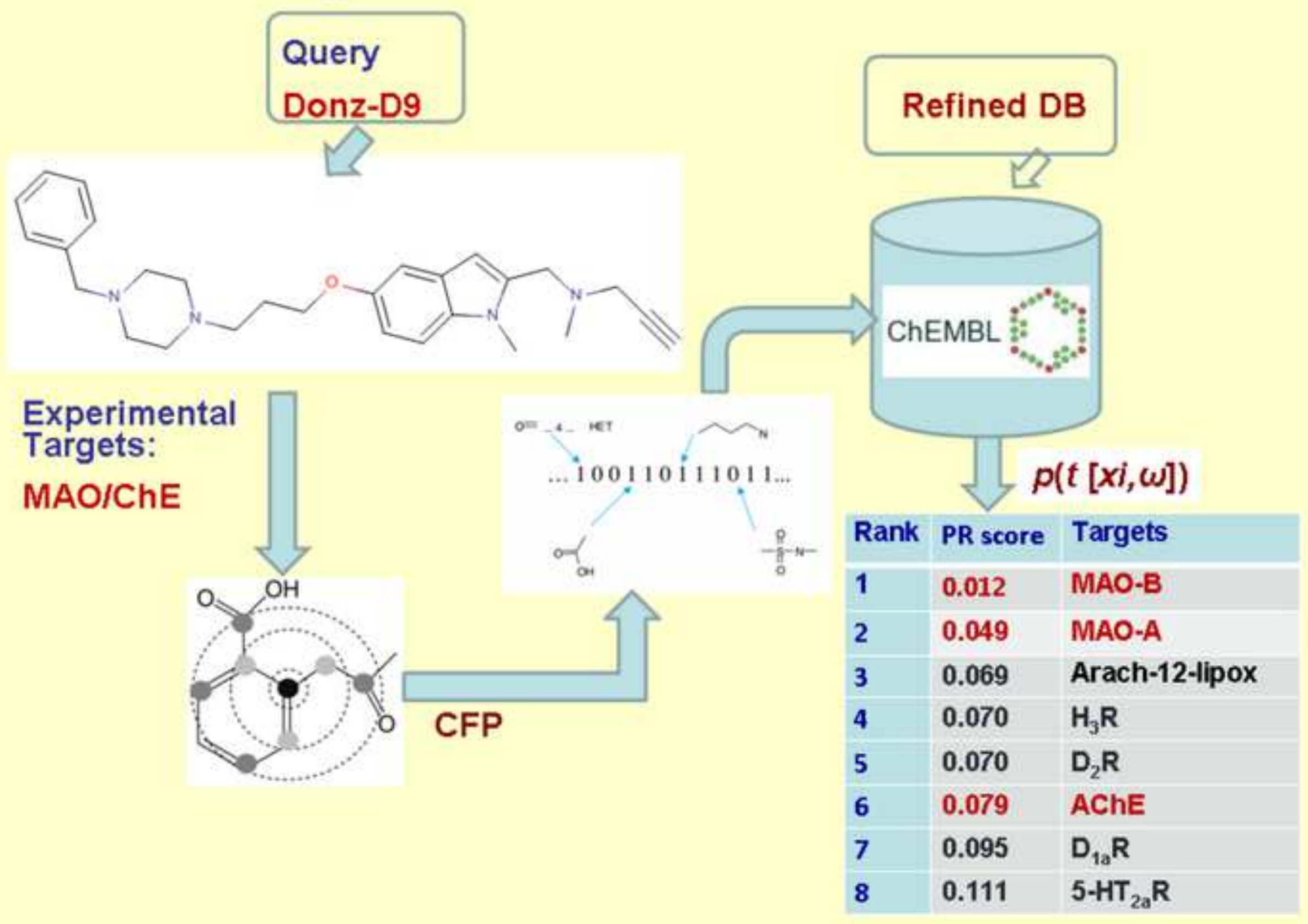




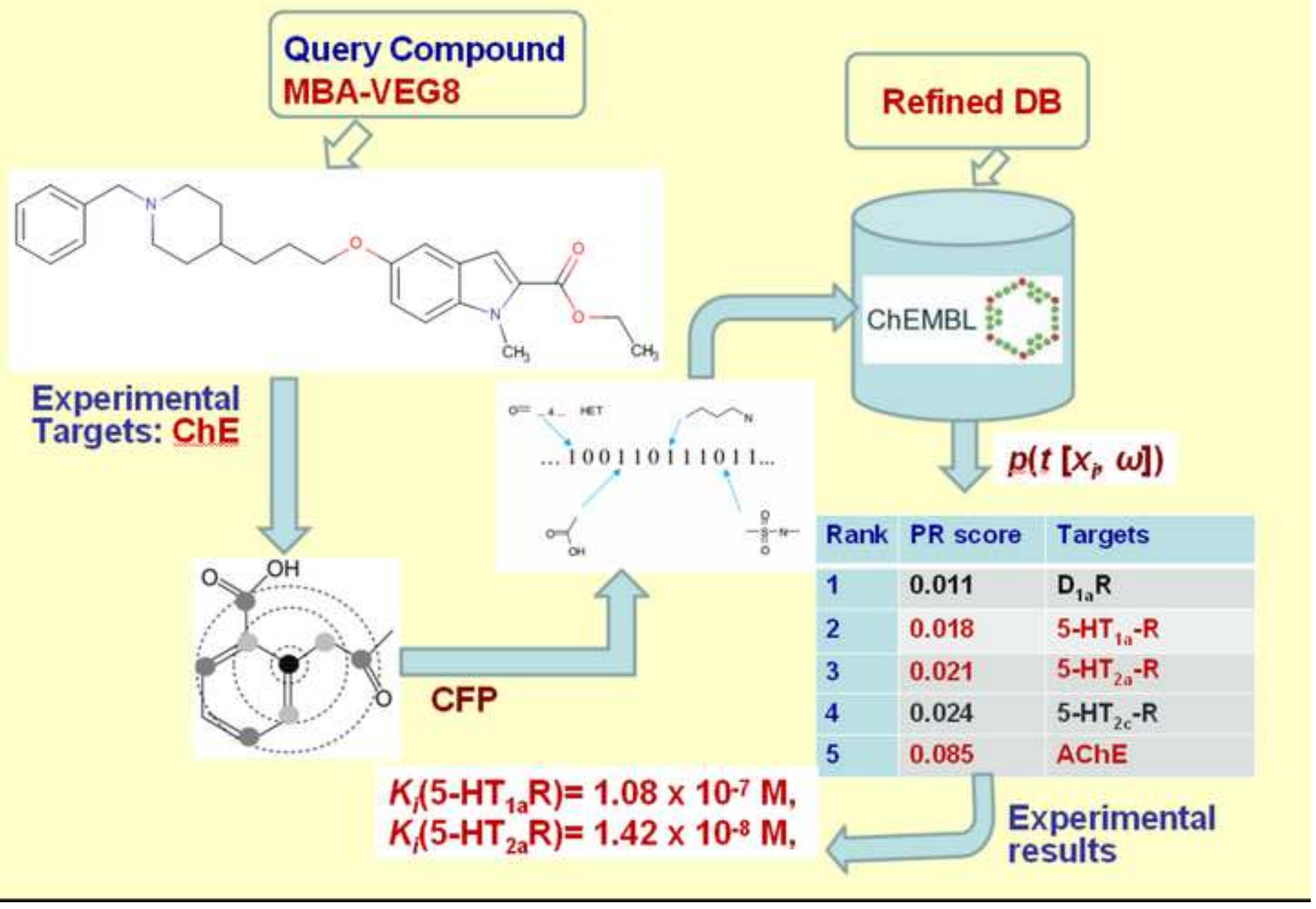




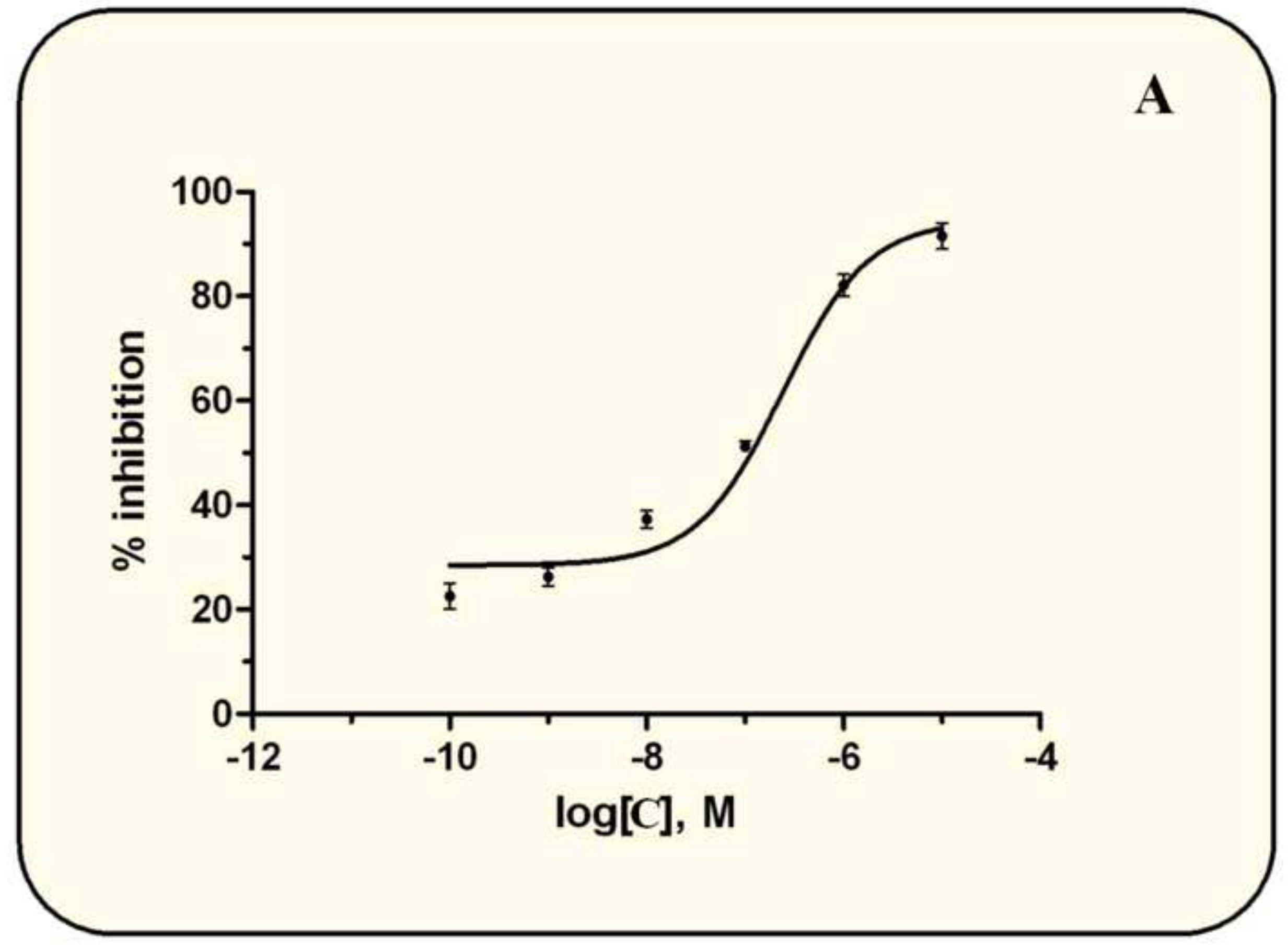




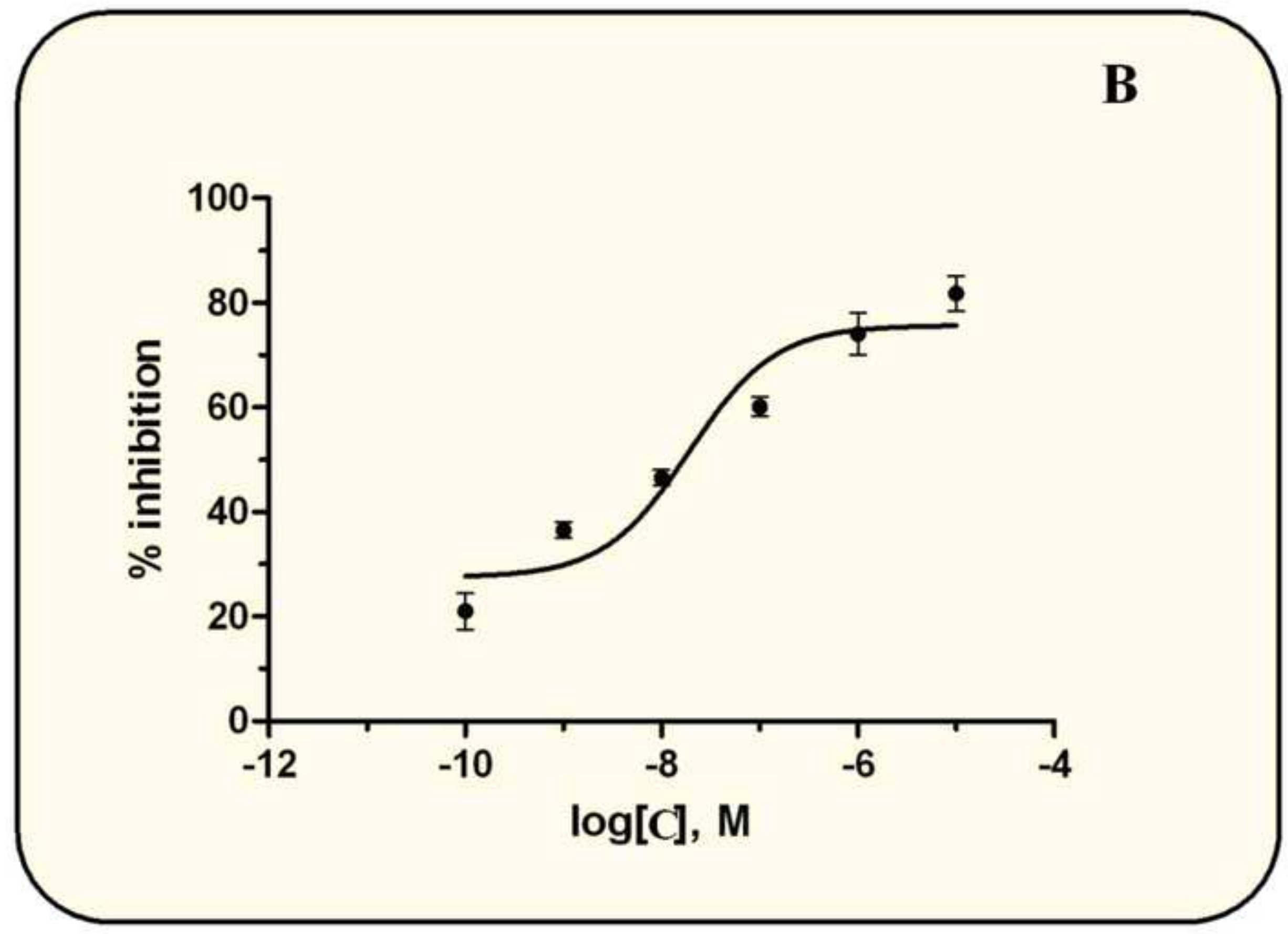



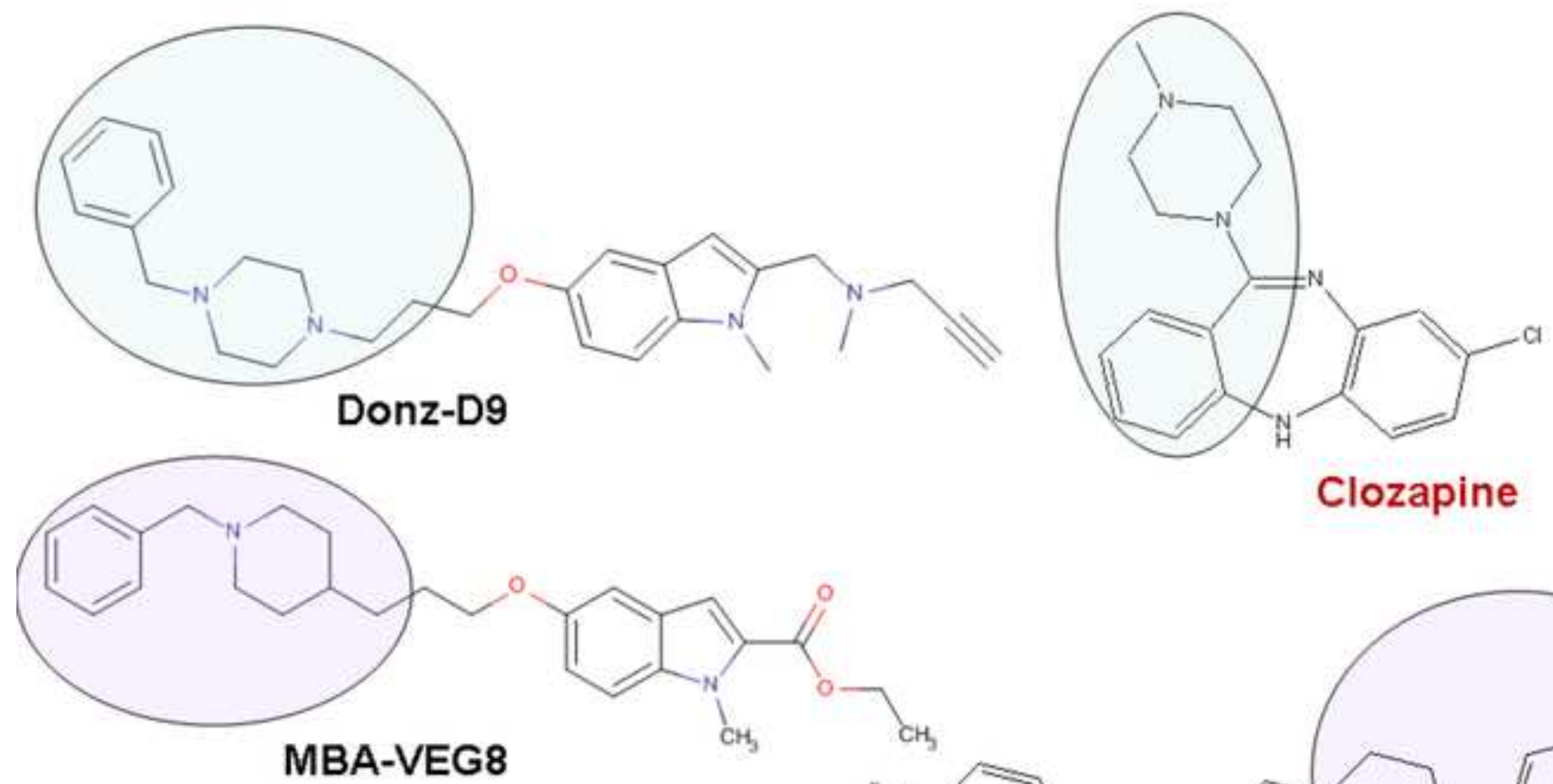

\section{Clozapine}
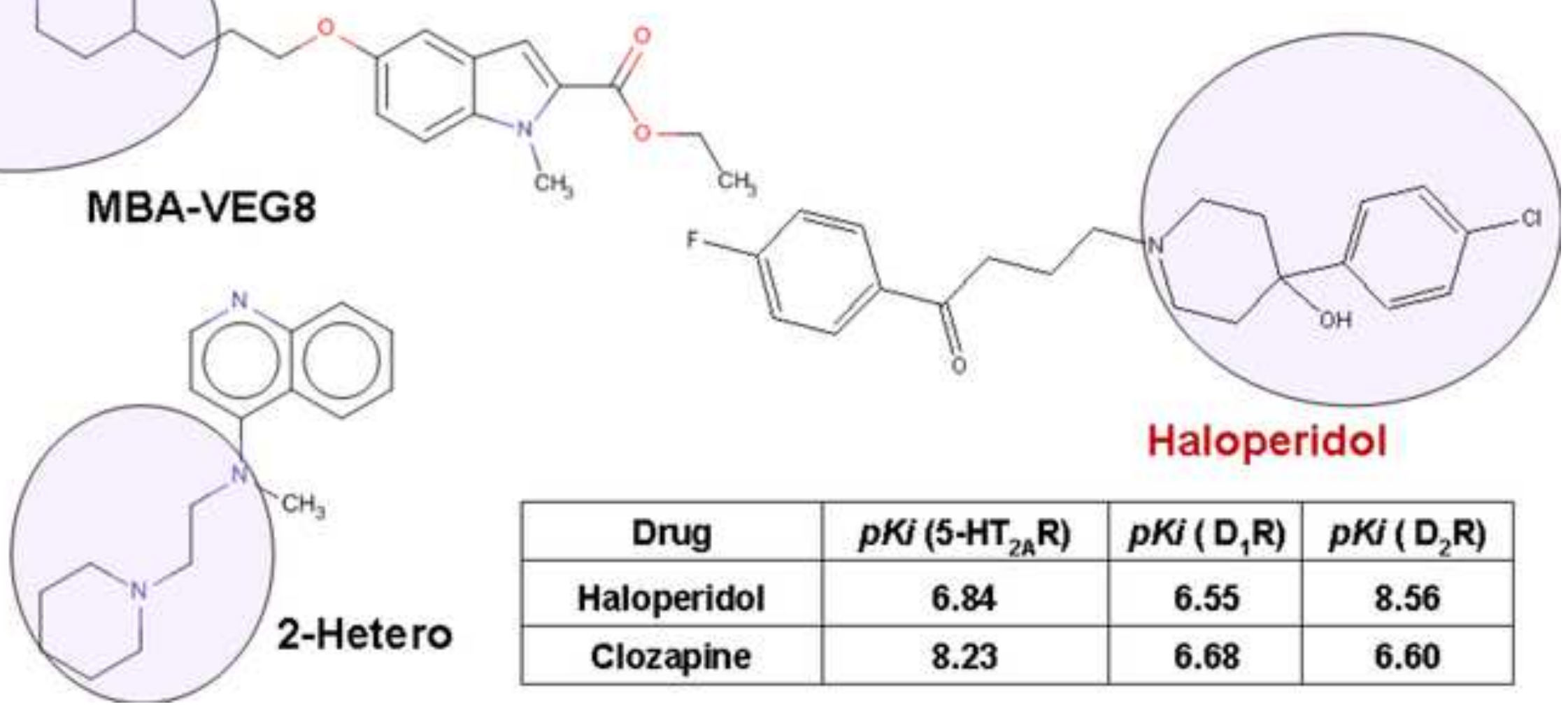

\begin{tabular}{|c|c|c|c|}
\hline Drug & $p K i\left(5-\mathrm{HT}_{2 \mathrm{~A}} \mathrm{R}\right)$ & $p K i\left(\mathrm{D}_{1} \mathrm{R}\right)$ & $p K i\left(\mathrm{D}_{2} \mathrm{R}\right)$ \\
\hline Haloperidol & 6.84 & 6.55 & 8.56 \\
\hline Clozapine & 8.23 & 6.68 & 6.60 \\
\hline
\end{tabular}


Electronic supplementary material-Table 1
Click here to download Electronic supplementary material: SuppITable1-ID-1-134-Chembl.xls

.

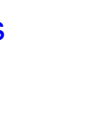

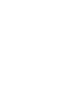

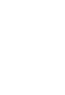

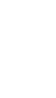

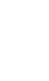
. . .

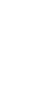
. .

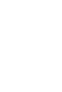

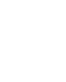

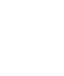

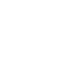

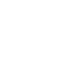

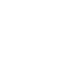

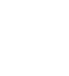

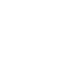

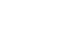

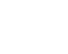

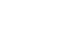

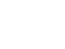

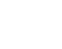

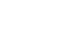

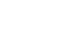

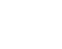

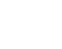

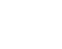

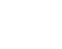

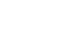

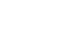

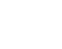

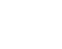

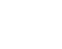

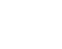

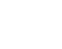

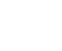

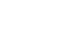

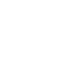

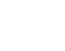

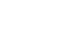

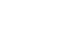


Electronic supplementary material-Table 2
Click here to download Electronic suppleme

Click here to download Electronic supplementary material: SuppITable2-ID-1-134-DrugBank.xls

Click here to download Electronic supplementary material: SupplTable2-1D-1-134-DrugBankxls

(1)

(1)

(1)

(1) (1) (1)

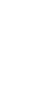

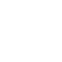

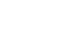

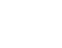

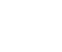

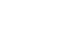

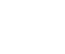

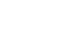
. . . . .

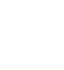

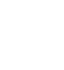
. .

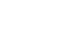

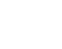

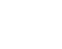

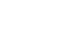

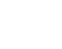

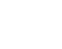

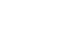

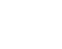

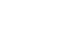

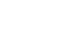

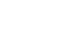

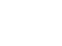

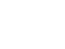
. 


\section{Supplement Figure 1}

Click here to download Electronic supplementary material: 1 Supplement Figure-1-all-1-134-DrugBank-NEW.tif 